\title{
Review
}

\section{Novel Lipid Mediators and Resolution Mechanisms in Acute Inflammation}

\author{
To Resolve or Not?
}

\author{
Charles N. Serhan \\ From the Center for Experimental Therapeutics and Reperfusion \\ Injury, Department of Anesthesiology, Perioperative and Pain \\ Medicine, Harvard Institutes of Medicine, Brigham and Women's \\ Hospital and Harvard Medical School, Boston, Massachusetts
}

Because inflammation is appreciated as a unifying basis of many widely occurring diseases, the mechanisms involved in its natural resolution are of considerable interest. Using contained, self-limited inflammatory exudates and a systems approach, novel lipid-derived mediators and pathways were uncovered in the resolution of inflammatory exudates. These new families of local mediators control both the duration and magnitude of acute inflammation as well as the return of the site to homeostasis in the process of catabasis. This new genus of specialized proresolving mediators (SPM) includes essential fatty acid-derived lipoxins, resolvins, protectins, and, most recently, maresins. These families were named based on their unique structures and potent stereoselective actions. The temporally initiated biosynthesis of SPM and their direct impact on leukocyte trafficking and macrophage-directed clearance mechanisms provide clear evidence that resolution is an active, programmed response at the tissue level. Moreover, SPM that possess anti-inflammatory (ie, limiting PMN infiltration) and proresolving (enhance macrophage uptake and clearance of apoptotic PMN and microbial particles) actions as well as stimulating mucosal antimicrobial responses demonstrate that antiinflammation and proresolution are different responses of the host and novel defining properties of these molecules. The mapping of new resolution circuits has opened the possibility for understanding mechanisms that lead from acute to chronic inflammation, or to the resolution thereof, as well as to potential, resolution-based immunopharmacological therapies. (Am J Pathol 2010, 177:1576-1591; DOI: 10.2353/ajpath.2010.100322)

\section{New Solution for Resolution of Acute Inflammation}

Surgical interventions, tissue injury, and microbial invasion each evoke acute inflammation that is ideally protective for the host and should be "self-limited." Resolution of this inflammatory response was believed to be passive and defined earlier by histopathology. ${ }^{1-4}$ It is now also widely accepted that uncontrolled inflammation is a unifying component in many diseases, ${ }^{5}$ including vascular diseases, ${ }^{6}$ neurological disorders, ${ }^{7}$ and host defense. ${ }^{2,5}$ Because resolution was believed to be passive, our initial contributions ${ }^{8-10}$ and those of other groups worldwide provided new evidence indicating that resolution is a biosynthetically active process. ${ }^{11-16}$ When we considered the routes between acute inflammation, chronic, or resolved, as decision paths, the self-limited response appeared to hold a solution to what endogenous mechanisms control the magnitude and duration of the acute response, including the cardinal signs of inflammation (Figure 1). Specifically, the author and colleagues systematically identified a novel genus of specialized pro-resolving mediators (SPM) that include nonredundant, distinct, new families of molecules that are locally acting mediators, namely resolvins, protectins,

Supported by National Institutes of Health grants DE019938, GM038765, and DK074448. The content is solely the responsibility of the author and does not necessarily reflect the official views of NIDCR, NIGMS, NIDDK, or the National Institutes of Health.

Accepted for publication May 25, 2010.

The author is inventor on patents assigned to Brigham and Women's Hospital and Partners HealthCare on the composition of matter, uses, and clinical development of anti-inflammatory and proresolving lipid mediators. These are licensed for clinical development. C.N.S. retains founder stock in Resolvyx Pharmaceuticals.

Address reprint requests to Prof. Charles N. Serhan, Director, Center for Experimental Therapeutics and Reperfusion Injury, Department of Anesthesia, Perioperative and Pain Medicine, Brigham and Women's Hospital, 77 Avenue Louis Pasteur, HIM 8, Boston, MA 02115. E-mail: cnserhan@ zeus.bwh.harvard.edu. 

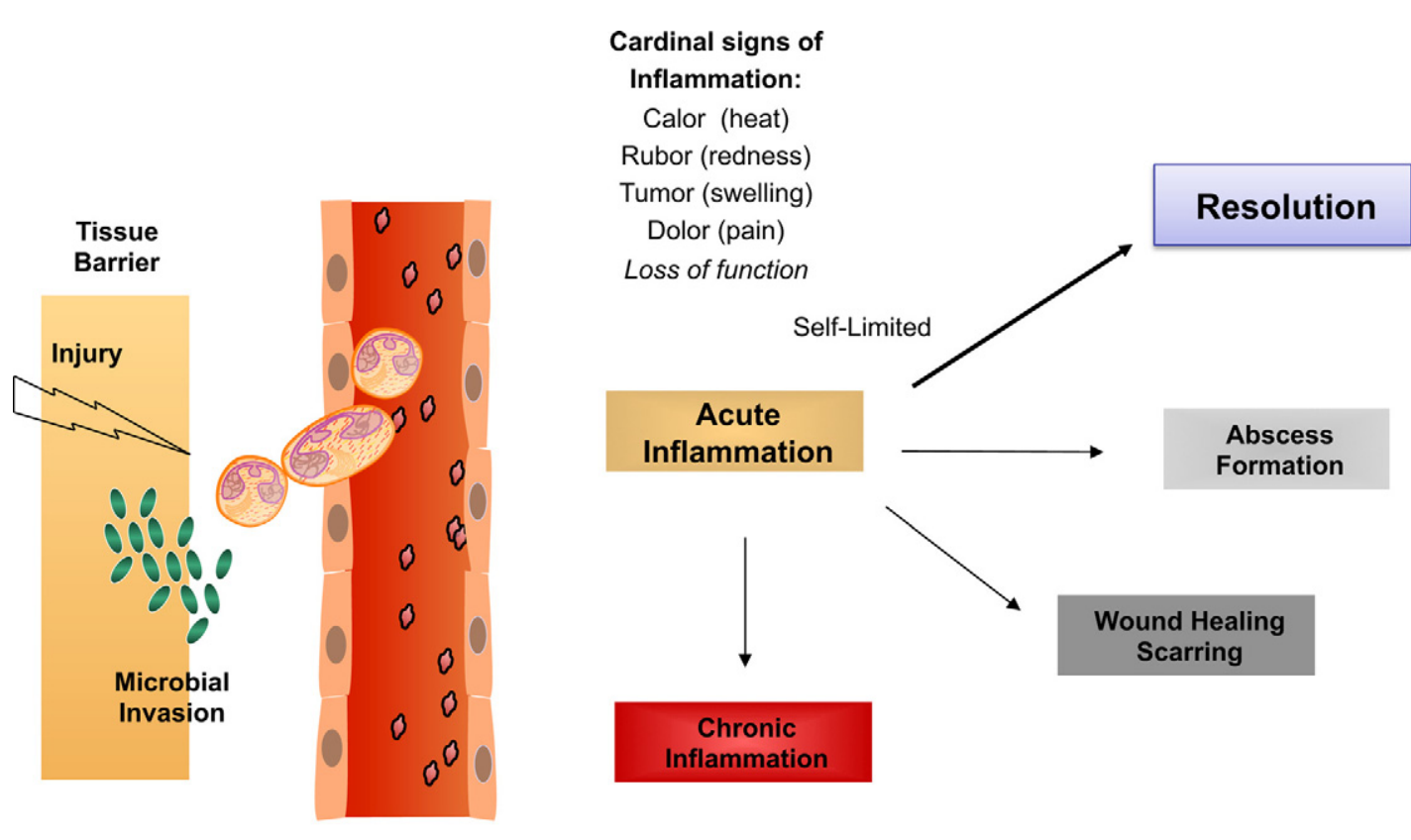

\section{Rheumatoid Arthritis \\ Periodontal Disease}

\section{Diabetes \\ Cardiovascular diseases \\ Asthma}

Figure 1. Decision paths in acute inflammation: resolution or chronic inflammation? Lipid mediators such as prostaglandins and leukotrienes play specific roles in the physiology of the acute inflammatory response. They can regulate many of the cardinal signs of inflammation. Self-limited inflammatory exudates permitted the identification and study of specialized pro-resolving mediators that stimulate the return to homeostasis.

and their aspirin-triggered forms. ${ }^{17,18}$ By definition, SPM are potent local-acting mediators and bioactive markers for this genus. Each limits PMN infiltration and enhances selective macrophage responses in a nonphlogistic (ie, not inducing inflammation or fever) fashion.

It has now become evident that the resolution program of acute inflammation remains largely uncharted and is critically needed to understand the pathophysiology of inflammation-resolution as well as to direct new therapeutic approaches. ${ }^{11,18,19}$ This review gives an overview and update on the systematic elucidation of resolution components activated in self-limited inflammation using an unbiased mediator-lipidomics approach in the author's lab, coupled with exudate proteomics, trafficking of leukocytes, and determination of the action of new chemical mediators in this milieu. Using this approach, we found resolvins (Rv), protectins $(P D)^{8,9,20}$ (Figure 2), and, recently, a new family of mediators produced by macrophages (M $\Phi)$ coined maresins (macrophage mediators in resolving inflammation [MaR]) that also regulate both neutrophil (PMN) and $M \Phi$ responses key for timely resolution. ${ }^{21}$

Although we are accustomed to thinking about the time required for recovery of tissues from acute inflammation as reflective of a local microenvironmental excess of proinflammatory mediators, it is evident that similar states can arise from diminished host resolution mechanisms. ${ }^{10}$ Failure to clear apoptotic PMN and cellular debris can lead to recurring inflammation and immune diseases. ${ }^{22-30}$ With new findings from disease models, ${ }^{17,28,31-34}$ it is possible that stimulating resolution pathways could improve treatment of a wide range of human disorders. Resolution of inflammation involves many cellular and tissue processes, including apoptosis, phagocytosis, cytokine/chemokine profiles and their scavenging mechanisms, as well as lymphatic drainage; ${ }^{22}$ these will not be addressed herein (for these, interested readers are directed to refs. 22-30). This review focuses on new concepts relevant in the pathophysiology of the fundamental process of resolution of acute inflammation born from uncovering novel endogenous lipid mediators in the author's laboratory that are controllers that activate endogenous anti-inflammation and proresolution circuits. For current reviews covering the biosynthesis of lipoxins, resolvins, and protectins, readers can consider references ${ }^{17,18}$ and references within. ${ }^{35}$

\section{Programmed Resolution of Acute Inflammation: Active Resolution versus Collateral Damage?}

If the ideal outcome of acute inflammation is complete resolution, ${ }^{1,36}$ it is now widely appreciated that uncontrolled inflammation can lead to tissue injury, chronic inflammation, scarring, and fibrosis. ${ }^{36}$ Controlled responses of phagocytes include destroying invading microbes and clearing sites of debris and apoptotic neutrophils (PMN). ${ }^{1}$ In an ungoverned host's response, PMN-mediated tissue injury leads to irreversible organ damage and associated diseases that are a major public health concern and financial 


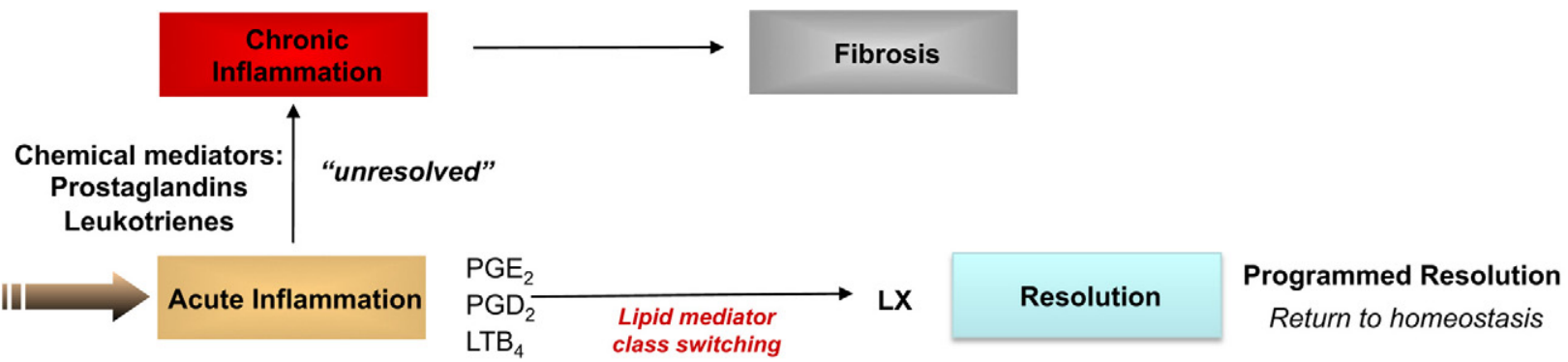

Families Specialized Pro-Resolving Mediators (SPM)

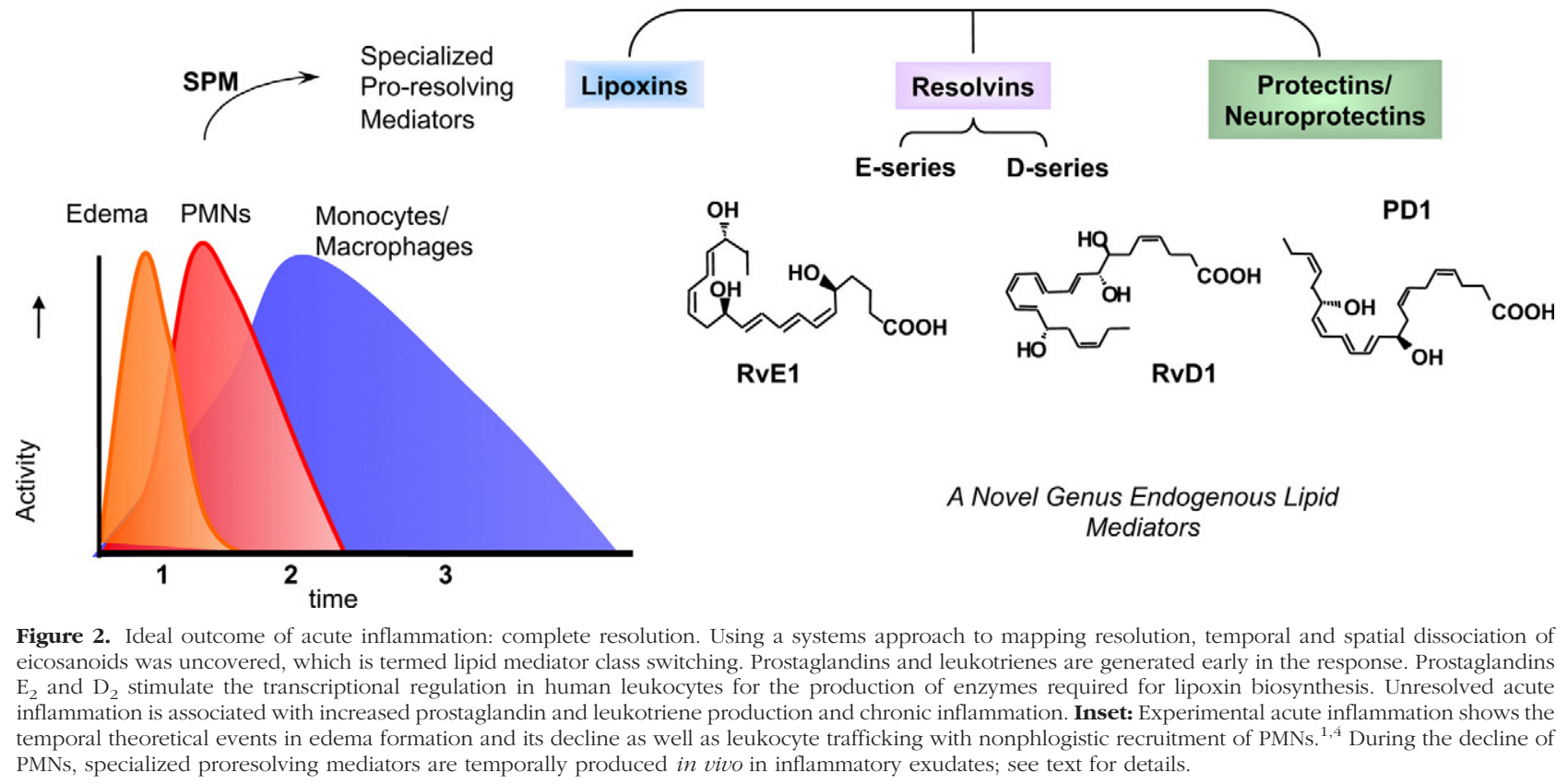

burden. Because PMN are the first line of host defense 37,38 $^{37}$ and rapidly respond to microbes as well as to soluble exoand endogenous stimuli (bacterial peptide chemoattractants, lipid mediators, for example, $\mathrm{LTB}_{4}$, chemokines, and complement components ${ }^{1}$ ), we considered it important to learn the host's mechanisms that control resolution. From ancient times, in the war of acute inflammation, pus/exudate was thought to passively retreat with the neutralization of the offending agents or microbes or dissipation of the chemotactic signals for leukocytes. ${ }^{39}$ The importance of pus as a noble substance was known to ancient physicians, hence, the Latin phrase Pus bonum et laudable or "good and laudable pus." This, according to Prof. Guido Majno, referred to whitish creamy pus (enriched with leukocytes), which was a "good or preferable" response, whereas a thin or malodorous pus suggested to the practitioner a poor defense and/or highly vicious bacteria. ${ }^{39}$ Today it is well appreciated that PMN play an essential role in host defense; their aberrant and prolonged activation can give rise to tissue injury observed in many chronic diseases. ${ }^{1,37,40}$ Trauma and surgical treatments can also lead to injury from within, where activated PMN are central in exacerbating the injured tissues by releasing noxious agents. Although intended for host defense from invading organisms/microbes, phago- cytes can amplify injury via the release of proinflammatory mediators, reactive oxygen species (ROS), and enzymes (Figure 1). This is well appreciated and helps explain the pathophysiologies observed in many clinical scenarios. ${ }^{41-44}$

\section{Specialized Anti-Inflammatory and Pro-resolving Mediators (SPM) in Programmed Resolution}

During acute self-limited inflammation, murine exudate phagocytes as well as human PMN and $\mathrm{M} \Phi$ biosynthesize specific, functionally distinct profiles of lipid-derived mediators (LM) that are agonist-dependent and temporally dissociated. Those that are proinflammatory include eicosanoids, such as classic prostaglandins (PG) and leukotrienes (LT). ${ }^{45,46}$ New LM profiles $^{8,9}$ including SPM (Figure 2) are generated by leukocyte exudates during resolution. This new genus, comprising four novel chemical mediator families, includes lipoxins (LX) from arachidonic acid, Rv and PD from $\omega$-3 essential fatty acids (EFA) (reviewed in ref. 18), and the new maresins. ${ }^{21} \mathrm{Rv}$ and PDs 
Table 1. Animal Disease Models*

\begin{tabular}{|c|c|c|c|}
\hline SPM & Disease model & Cellular mechanism of action & References \\
\hline \multirow[t]{5}{*}{ Resolvin E1 } & $\begin{array}{l}\text { Skin } \\
\text { Oral inflammation, } \\
\text { periodontitis }\end{array}$ & $\begin{array}{l}\text { Stops neutrophil recruitment in dorsal pouch } \\
\text { Reduces neutrophil infiltration; prevents } \\
\text { connective tissue and bone loss; promotes } \\
\text { healing of diseased tissues; regenerates lost } \\
\text { soft tissue and bone }\end{array}$ & $\begin{array}{l}\text { Serhan et al. }{ }^{8} \\
\text { Hasturk et al. }{ }^{53}\end{array}$ \\
\hline & Peritonitis & $\begin{array}{l}\text { Stops neutrophil recruitment; regulates } \\
\text { chemokine/cytokine production } \\
\text { Promotes lymphatic removal of phagocytes }\end{array}$ & $\begin{array}{l}\text { Bannenberg et al. }{ }^{40} \\
\text { Arita et al. } \\
\text { Schwab et al. }\end{array}$ \\
\hline & Asthma & $\begin{array}{l}\text { Reduces airway inflammation; stimulates } L_{X A_{4}} \text {; } \\
\text { reduces SRS-A }\end{array}$ & Haworth et al. ${ }^{49}$ \\
\hline & Ocular & Regulates neovascularization, angiogenesis & $\begin{array}{l}\text { Connor et al. } .^{51} \\
\text { Jin et al. } \\
\text { Tian et al. }\end{array}$ \\
\hline & Colitis & $\begin{array}{l}\text { Limits PMN recruitment and proinflammatory gene } \\
\text { expression; improves survival; reduces weight } \\
\text { loss }\end{array}$ & $\begin{array}{l}\text { Arita et al. }{ }^{47} ; \text { Ishida } \\
\quad \text { et al. }{ }^{58}\end{array}$ \\
\hline Resolvin E2 & Peritonitis & Reduces PMN infiltration & $\begin{array}{l}\text { Tjonahen et al. }{ }^{59} \text {; } \\
\text { Ogawa et al. }{ }^{60}\end{array}$ \\
\hline \multirow[t]{4}{*}{ Resolvin D1 } & Peritonitis & Limits PMN recruitment & $\begin{array}{l}\text { Hong et al. } \\
\text { Sun et al. }\end{array}$ \\
\hline & Skin & Stops PMN recruitment (air pouch) & $\begin{array}{l}\text { Serhan et al. }{ }^{9} ; \\
\quad \text { Hong et al. }{ }^{20}\end{array}$ \\
\hline & Kidney ischemia-reperfusion & $\begin{array}{l}\text { Protects from ischemia-reperfusion-induced } \\
\text { kidney damage and loss of function; regulates } \\
\text { macrophages and protects from fibrosis }\end{array}$ & Duffield et al. ${ }^{61}$ \\
\hline & Ocular & Protects against neovascularization & Connor et al. ${ }^{51}$ \\
\hline Resolvin D2 & Peritonitis, sepsis & $\begin{array}{l}\text { Reduce peritonitis and increase phagocyte } \\
\text { reactive oxygen species bacterial killing }\end{array}$ & Spite et al. ${ }^{42}$ \\
\hline \multirow[t]{6}{*}{ NPD1/Protectin D1 } & Stroke & $\begin{array}{l}\text { Stop leukocyte infiltration, inhibits NF- } \kappa \text { B and } \\
\text { cyclooxygenase- } 2 \text { induction }\end{array}$ & Marcheselli et al. ${ }^{62,63}$ \\
\hline & Peritonitis & $\begin{array}{l}\text { Stops neutrophil recruitment; regulates } \\
\text { chemokine/cytokine production } \\
\text { Promotes lymphatic removal of phagocytes } \\
\text { Regulates T-cell migration }\end{array}$ & $\begin{array}{l}\text { Bannenberg et al. }{ }^{40} \text {; } \\
\text { Arita et al. }{ }^{54} \\
\text { Schwab et al. }{ }^{55} \\
\text { Ariel et al. }\end{array}$ \\
\hline & Asthma & $\begin{array}{l}\text { Protects from lung damage, airway inflammation } \\
\text { and airway hyperresponsiveness } \\
\text { Protectin D1 in human breath condensates } \\
\text { appears diminished in asthmatics }\end{array}$ & Levy et al. ${ }^{65}$ \\
\hline & Kidney ischemia-reperfusion & $\begin{array}{l}\text { Protects from ischemia-reperfusion-induced } \\
\text { kidney damage and loss of function; regulates } \\
\text { macrophages and is anti-fibrotic }\end{array}$ & $\begin{array}{l}\text { Duffield et al. }{ }^{61} ; \\
\text { Hassan et al. }{ }^{66}\end{array}$ \\
\hline & Ocular & $\begin{array}{l}\text { Protects in neovascularization } \\
\text { Protects in retinal injury }\end{array}$ & $\begin{array}{l}\text { Connor et al. }{ }^{51} \text {; } \\
\text { Mukherjee et al. } \\
\text { Sheets et al. } \\
\text { He and Bazan }\end{array}$ \\
\hline & $\begin{array}{l}\text { Alzheimer's disease, } \\
\text { neurodegeneration }\end{array}$ & $\begin{array}{l}\text { Diminished protectin D1 production in human } \\
\text { Alzheimer's disease }\end{array}$ & Lukiw et al. ${ }^{69}$ \\
\hline Maresin 1 & Peritonitis & $\begin{array}{l}\text { Reduces PMN migration and enhances } \mathrm{M} \Phi \\
\text { phagocytosis }\end{array}$ & Serhan et al. ${ }^{21}$ \\
\hline
\end{tabular}

${ }^{*}$ The actions of each of the main resolvins and protectins (that is, RvE1, RVD1, and PD1) were confirmed with compounds prepared by total organic synthesis (see Figure 3, text, and cited references for further details). RvE2 total synthesis and bioactions were recently confirmed. ${ }^{60}$

SPM, specialized pro-resolving mediators.

have proven to be very potent when administered to a number of inflammation-associated animal models of human disease. These include murine colitis, ${ }^{47}$ peritonitis, ${ }^{9,48}$ dermal inflammation, ${ }^{9}$ asthma, ${ }^{49,50}$ and ocular disease ${ }^{51,52}$ (Table 1;8,9,20,21,40,42,47,49,51,52,54-69). Of interest, a specific $\mathrm{Rv}, \mathrm{RvE1}$, reduces oral infectious inflammation ${ }^{53}$ and associated bone loss, inhibits ADP-dependent platelet aggregation, ${ }^{70}$ and regulates both dendritic cells ${ }^{54}$ and effector $T$ cells. ${ }^{71}$ Recently, in the first human clinical trial, a resolvin analog effectively reduced dry eye symptoms (http:// eyedocnews.com/002059-resolvyx-announces-positivedata-from-trial-of-resolvin-rx-10045-for-dry-eye/, last accessed August 18, 2010), ${ }^{26}$ providing evidence in humans that SPM can be useful in a wide range of inflammatory disorders.
During natural resolution as well as experimental resolution with a fixed time $0, P M N$ initially defend the tissue (ie, kill microbes and clear debris) and then are lost from inflammatory sites; mononuclear cells and $\mathrm{M} \Phi$ are recruited in a nonphlogistic manner; and tissues return to homeostasis., 1,4,39 In contained exudates, we found that LM production is temporally dissociated. Initially, PG and LT appear with PMN entry, followed by $L X$ and $R v$ biosynthesis in resolution. ${ }^{8,72}$ These results first demonstrated that the type of eicosanoid and/or LM produced locally is both spatial and temporally regulated (Figure 2). This new concept of resolution-phase mediators and their potent actions has been confirmed ${ }^{24,25,66}$ and extended, ${ }^{73-75}$ includ- 


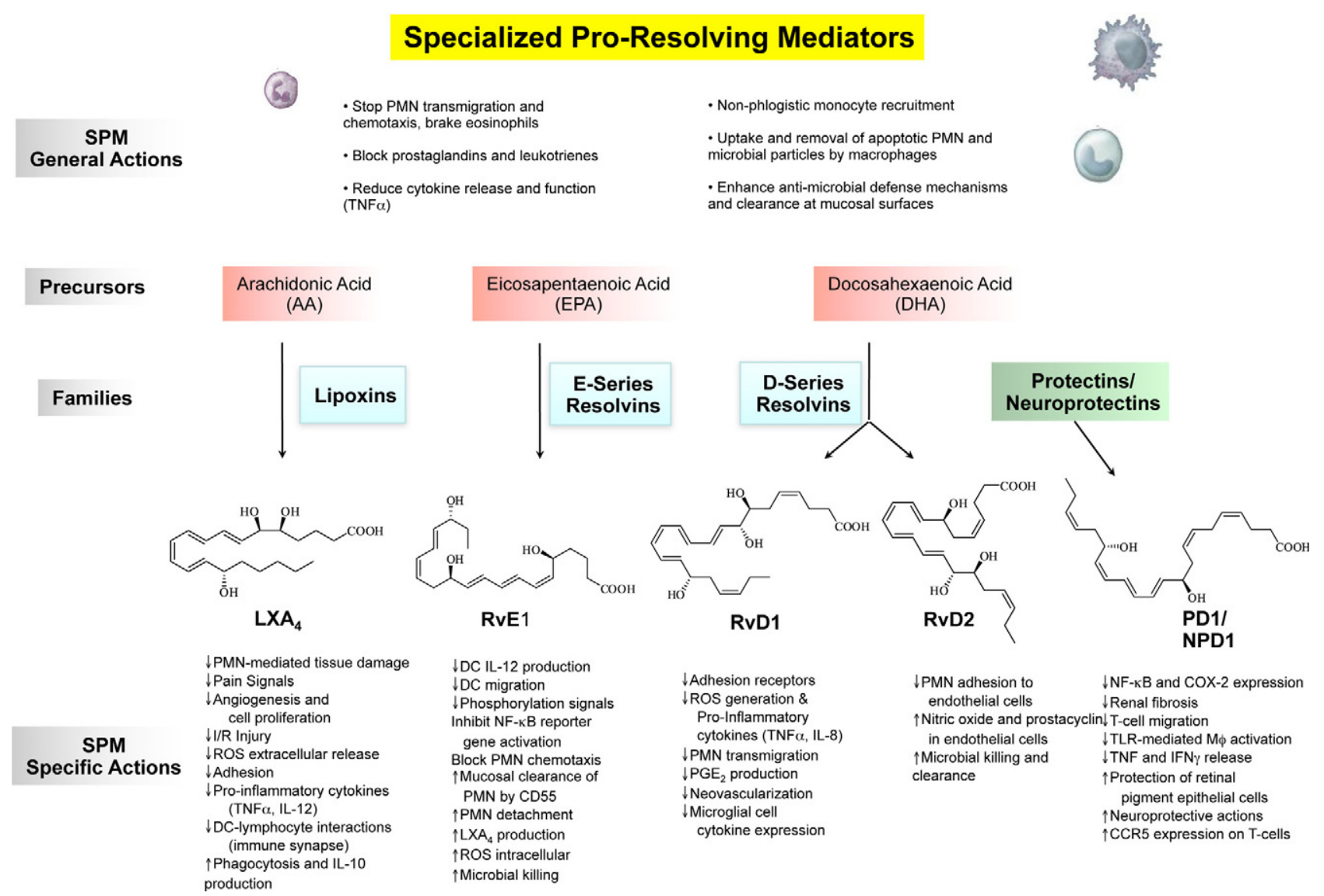

Figure 3. The genus of specialized proresolving mediators: structures and actions. The SPM genus is defined by reduction or limiting further PMN infiltration and reduction of lipid mediators and cytokines. SPM also stimulate the nonphlogistic recruitment of mononuclear cells and the stimulation of macrophages to phagocytose apoptotic PMN microbes and microbial particles. The family precursors are substrates for their respective conversion to lipoxins, E-series resolvins, D-series resolvins, and protectins. The main structures of key SPM genus members are depicted; the complete stereochemistry of each has been determined, and their physical properties and bioactions have been confirmed by total organic synthesis; see text for details.

ing the temporal relationship between $L T$ and $L X$ in human disease. ${ }^{76-78}$

Initial acute inflammation can also progress to an abscess or become chronic, which may lead to fibrosis. ${ }^{1,79}$ The same sets of LM initially made (ie, PG and LT) were believed to amplify recurring bouts of acute inflammation that evolve to chronic disease. ${ }^{1,80}$ Specific Rv and LX administered early can circumvent fibrosis. ${ }^{35,61,81,82}$ These new findings raise the very likely possibility that chronic human diseases, such as arthritis, Crohn's disease, and even certain cancers, ${ }^{11,79,83}$ may in part reflect diminished local biosynthesis of proresolving signals. Among such endogenous resolution signals, identification of SPM remained unknown, likely because, once produced at the site, these autacoids are relatively short-lived and are generated often via transcellular biosynthesis routes within exudates ${ }^{8,9}$ to act locally (Figures 3 and 4).

\section{What is Proresolving? A New Bioaction for Chemical Mediators}

Resolution is the outcome when the initial injury or microbial invasion is limited, and the injurious stimuli or microbes are successfully neutralized, enabling the site to return to normal. ${ }^{1}$ Steps in resolution include the following: i) cessation of PMN infiltration (see Figure 2, left corner); ii) vascular permeability/edema returns to normal; iii) dead PMN (mostly via apoptosis) leave the site; iv) nonphlogistic infiltration of monocytes $/ \mathrm{M}^{84}$; and v) M $\Phi$ removal of apoptotic PMN, foreign microbes/agents, and necrotic debris. ${ }^{55,81,85}$ Assigning molecular events in resolution in human tissues was hindered until relatively recently. ${ }^{18,86-88}$ Using new, unbiased, liquid chromatography-mass spectrometry-based approaches, namely LM-lipidomics-coupled proteomics with informatics, we identified novel mediators and introduced resolution indices ${ }^{40,55,89}$ that can now translate this fundamental process between experimental systems and to humans (see below).

With this strategy using LM-lipidomics, genetically engineered murine and human cell systems (human PMN and exudates), we obtained the first evidence that resolution is actively "turned on," ${ }^{8,9,72}$ challenging the notion believed for more than 100 years that resolution was a passive process. ${ }^{39,90}$ These new SPM possess unique multilevel actions that include limiting PMN entry, enhancing M $\Phi$ clearance of apoptotic cells and microbes, ${ }^{55,91}$ fighting infection, ${ }^{43,92}$ but yet apparently not being immunosuppressive. ${ }^{31,42}$ A gene array approach with $L X$ and Rv uncovered previously unknown links between LM and host antimicrobial responses that stimulate 


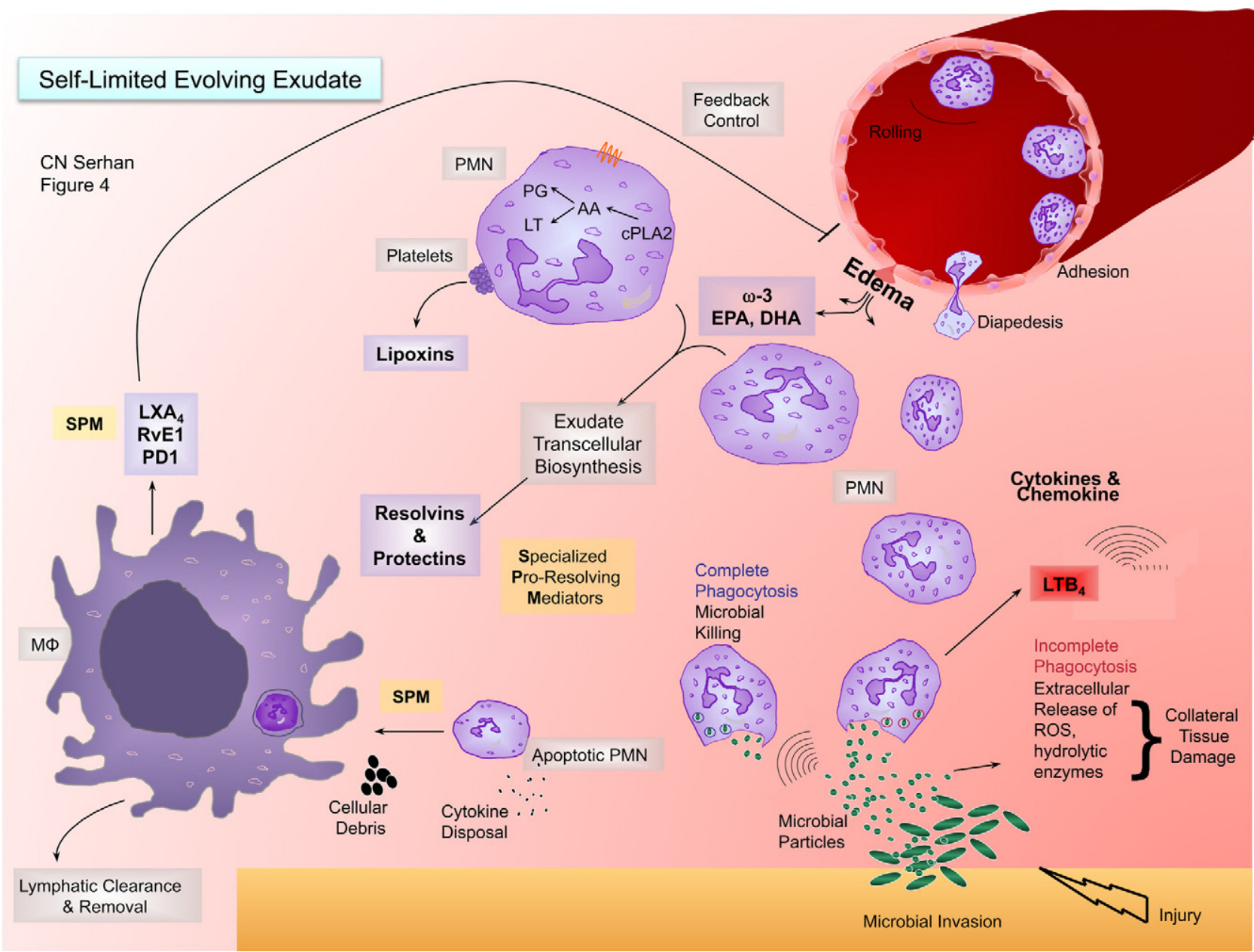

Figure 4. SPM-regulated processes in resolution and a new role for edema in delivering essential fatty acids. This illustration depicts a self-limited evolving exudate with the key roles of specialized proresolving mediators (SPM), substrate delivery, and leukocyte trafficking. i) Lower right-hand corner: microbial invasion in injury initiates chemotactic signals that initially summon neutrophils from postcapillary venules. Neutrophils arrive to the site via diapedesis and chemotaxis. A key chemoattractant of the eicosanoids in the process is leukotriene $\mathrm{B}_{4}$. There is also a wide range of cytokines and chemokines that stimulate neutrophil recruitment in this important and fundamental process. ii) As neutrophils congregate in the contained inflammatory exudate, cell-cell interactions (eg, with platelets in transcellular biosynthesis generated between PMN and platelets) initiate the transcellular biosynthesis of lipoxins. Newly arrived and older PMN within the exudate interact to produce resolvins and protectins via transcellular biosynthesis. During this process, edema carries the $\omega$ - 3 essentially fatty acids EPA and DHA from the blood into the exudate for their utilization. iii) Once resolvins and protectins are produced, these SPM stimulate macrophages to take up apoptotic PMN and cellular debris. Additionally, the corpses of apoptotic PMN can serve to bind chemokines and cytokines for their disposal. SPM enhance macrophage uptake and clearance. iv) Macrophages phagocytose apoptotic PMN. This process is stimulated by SPM and is an anti-inflammatory and nonphlogistic process. Rather than producing proinflammatory mediators during phagocytosis, such as LTB 4 , TNF, and IL-1, these macrophages produce lipoxins, resolvins, and $\mathrm{NPD} 1 / \mathrm{PD} 1$ that, in turn, inhibit further edema through a feedback mechanism. This hypothetical course of events and time course help the contained inflammatory exudate to resolve as well as efficiently combat infection and return to homeostasis from local tissue injury.

mucosal epithelial cells to produce antimicrobial peptides. $^{43,92}$ Because LX and Rvs control inflammation by stimulating resolution without immune suppression, limiting local inflammation by reducing PMN, and enhancing the M $\Phi$ cleanup, a new chemical mediator function for SPM was introduced to describe their temporal biosynthesis and novel functional roles. Figure 3 illustrates the actions and structure of the key family members of the SPM genus.

\section{SPM in Resolution: Agonist of Nonphlogistic Responses}

Lipoxin $A_{4}\left(L X A_{4}\right)$ and $L X B_{4}$ were the first anti-inflammatory and proresolving lipid mediators recognized. ${ }^{35} \mathrm{Li}$ poxins are lipoxygenase-derived eicosanoids, derived enzymatically from arachidonic acid, an $\omega-6$ fatty acid that is released and mobilized during inflammation. ${ }^{45,93}$ In human systems, lipoxins are biosynthesized predominantly via transcellular metabolic events engaged during leukocyte interactions with mucosal cells, that is, epithelia of the gastrointestinal tract or bronchial tissue and within the vasculature during platelet-leukocyte interactions (reviewed in refs. 18, 35).

Contained, self-limited inflammatory exudates were initiated in the murine dorsal air pouch and used to determine the formation and roles of endogenous lipoxin $A_{4}$ $\left(\mathrm{LXA}_{4}\right)$ in resolution. ${ }^{72}$ TNF- $\alpha$ gives a typical acute-phase response with rapid $\mathrm{PMN}$ infiltration and local generation of prostaglandins and leukotrienes. In this setting of contained exudates, the eicosanoid biosynthesis underwent temporal changes we termed a "class switch." As exudates evolved, the eicosanoid profiles switched and the 
lipid mediators made within that milieu changed with time, ${ }^{72}$ also observed in the resolution of Lyme disease infections in mice ${ }^{75}$ and in humans ${ }^{76,77}$ with poststreptococcal nephritis. ${ }^{76}$ Arachidonate-derived eicosanoids changed from the initial production of prostaglandins and leukotrienes to lipoxins. The appearance of lipoxins within inflammatory exudates was concomitant with the loss of PMN and resolution of inflammation. ${ }^{72}$ Because this class switch was driven in part by prostaglandins $E_{2}$ and $D_{2}$ that regulate the transcription of enzymes involved in lipoxin biosynthesis in human leukocytes, ${ }^{72}$ we introduced the concept that " $\alpha$ signals omega." "10 Thus, initial events in the acute response govern the magnitude and duration to resolution.

Within exudates, PMN undergo either apoptosis or necrotic cell death. As part of resolution, lipoxins signal macrophages to enhance engulfment of apoptotic PMN.$^{81}$ Lipoxins are potent chemoattractants for human monocytes but in a nonphlogistic fashion as they promote infiltration of mononuclear cells without stimulating release of proinflammatory chemokines or activation of proinflammatory gene pathways and products..$^{84} \mathrm{LX}$ have specific actions in the pico- to nanogram range, limiting PMN recruitment, chemotaxis, and adhesion, acting essentially as a braking signal for PMN-mediated tissue injury, which have now been established in vivo in humans. ${ }^{25,35}$ Notably, a stable lipoxin analog, 16-phenoxy$\mathrm{LXA}_{4}$, stimulates mononuclear cells to produce IL-1Ra, the endogenous receptor antagonist. ${ }^{94}$

\section{Anti-inflammatory Versus Proresolution}

Endogenous anti-inflammation alone is different and only part of the cellular processes linked to proresolution that are regulated by SPM. Proresolving actions can also encompass anti-inflammatory and are newly defined via SPM. For example, SPM stimulate macrophages to clear cytokines-chemokines and cellular debris as well as apoptotic PMN. ${ }^{95}$ These are not actions classified with antiinflammatory substances, that is, NSAIDs, which reduce prostaglandin biosynthesis by inhibiting enzymatic pathways in inflammation, ${ }^{96,97}$ hence reducing the classic signs of inflammation. ${ }^{1}$ SPM possess anti-inflammatory actions in that they reduce PMN infiltration, which in turn limits PMN-mediated tissue damage and resulting local amplification of proinflammatory signals (illustrated in Figure 4). Frequently, classic anti-inflammatory compounds do not stimulate phagocytosis. In this regard, SPM are agonists that stimulate cytoskeletal/shape changes in PMN, limiting diapedesis and tissue accumulation but not interfering with their antimicrobial activity (see below). This fundamental difference for SPM actions opened a new appreciation of active resolution as a programmed tissue response that involves separate regulation of PMN and macrophage activities in vivo. ${ }^{55} \mathrm{An}$ international consensus report has defined these differences and their potential contribution in chronic disease as a failure in resolution mechanism. ${ }^{11}$

\section{Aspirin-Triggered Lipid Mediators: Resolution and Omega-3 EFA Connection}

The molecular terrain of resolution offers new insights into disease pathogenesis and many opportunities for targeting new therapeutics. ${ }^{88,98}$ SPM not only serve regulatory roles in the physiological events of inflammation, but specific enantiomeric or R (epi) forms triggered by aspirin, termed aspirin-triggered forms of LX and Rv, may also be effectors of well-established anti-inflammatory therapies, such as aspirin, glucocorticoids, and statins. ${ }^{18,99-102}$ The first, uncovered in coincubations of human PMN and endothelial cells, ${ }^{103}$ AT-LX, have now been documented in humans in a randomized trial. ${ }^{104}$ Production of AT-LXA 4 shows both gender and age dependence, that is, higher in females and reduced in older males. ${ }^{105}$ Given the potent AT-LX actions in reducing PMN-mediated tissue injury, vascular permeability, and local inflammation, ${ }^{106,107}$ AT-LX were recently demonstrated in humans and regulated PMN influx in forearm blisters, accounting for low-dose aspirin's anti-PMN actions. ${ }^{25}$ This is of interest because $L X$ and AT-LX reduce inflammatory pain processing. ${ }^{108}$ Hence, aspirin has an unexpected impact on resolution. In humans, aspirin "jump-starts" this process via its ability to trigger the endogenous biosynthesis of lipid mediators. ${ }^{25,54,104}$

As early as 1929, the importance of dietary EFA was demonstrated in maintaining health in rodents and reduced incidence of infection and inflammation. ${ }^{109}$ Many human studies, ${ }^{110-112}$ including the GISSI in cardiovascular disease, show potential benefits of $\omega-3$ (n-3) EFA, including docosahexaenoic acid (DHA) and eicosapentaenoic acid (EPA), in human health. Recent evaluations establish the positive odds ratio for n-3 EFA in reducing cardiovascular disease, ${ }^{113}$ and the Jupiter trial confirms the importance of inflammation in cardiovascular disease. ${ }^{6}$ The mechanisms for the beneficial effects of $n-3$ EFA are of interest and remain to be fully established in humans. Rv, PD, and maresins are biosynthesized in exudates from n-3 EFA (EPA and DHA).

\section{Resolvins and Protectins}

Resolvins are enzymatically biosynthesized within resolving exudates. They were initially identified and elucidated using LC-MS-MS-based lipidomics ${ }^{8,9}$ and informatics ${ }^{114}$ together with bioassay systems. The term resolvins (resolution-phase interaction products) refers to endogenous chemical mediators that are biosynthesized from the major $\omega-3$ fatty acids, EPA and DHA, denoted E series (RvE) and $\mathrm{D}$ series (RvD) resolvins, respectively. ${ }^{9}$ Subsequently, the complete structural elucidation of these bioactive mediators and related compounds was confirmed by total organic synthesis. ${ }^{8,9,20,54,115}$ Resolvins can also be produced via COX-2-dependent reactions in the presence of aspirin, yielding 'aspirin-triggered' (AT) forms, as well as nonaspirin-dependent biosynthetic routes. ${ }^{116}$ Both RvD1 and AT-RvD1, for example, limit PMN transendothelial migration and infiltration in vivo ${ }^{9,48}$ and regulate leukocyte trafficking to sites of inflammation 
as well as clearance of neutrophils from mucosal surfac$\mathrm{es}^{43}$ in pg-ng amounts.

Because the immune regulatory actions of n-3 EFA and their roles in human health and diseases, such as cardiovascular disease, cancer, and inflammation, are widely considered, ${ }^{111,117}$ the potent stereoselective actions of Rv and PD could offer a potential link between $\omega-3$ EFA to molecular functions in resolution and organ protection. RvE1 is biosynthesized from EPA and interacts with specific receptors to control inflammatory cells ${ }^{54}$; mice deficient in these receptors confirm the anti-inflammatory role of these receptors. ${ }^{118}$ In addition, fat- 1 transgenic mice producing higher endogenous levels of n-3 EFA show reduced inflammatory status and elevated levels of Rv and PD. ${ }^{119}$ When administered, each SPM reduces disease and stimulate resolution ${ }^{47,50,51,57}$ (Table 1; 8,9,20,21,40,42,47,49,51,52,54-69). The main biosynthetic route with DHA for Rv and PD proceeds via a 17S-hydro(peroxy)docosahexaenoic intermediate produced by a lipoxygenase (ie, 12/15-LOX in mice and 15-LOX type I in human leukocytes).

We established the complete stereochemistry of RvD1, ${ }^{48}$ confirming its original structural assignment ${ }^{9}$ and anti-inflammatory actions by total organic synthesis as well as RvD2 (Figure 3). ${ }^{42}$ With aspirin therapy, acetylated COX-2 produces aspirin-triggered 17R-epimers of Rvs and PD as well as enhances their formation. ${ }^{9,48}$ Genetic deficiency or overexpression of murine 12/15LOX regulates production of SPM and alters their responses to both thermal injury ${ }^{120}$ and extent of atherosclerosis. ${ }^{34}$ Transgenic rabbits overexpressing 12/ 15-LOX give enhanced LX production, reduced inflammatory status, and periodontal disease ${ }^{121}$ as well as reduced atherosclerotic lesions in mice and rabbits via elevated production of SPM. ${ }^{34}$ Recently, the anti-inflammatory and tissue protective role of 12/15-LOX and LXA axis in regulating TNF $\alpha$ were confirmed and demonstrated in two murine arthritis models. ${ }^{29}$ This is also the initial LOX in the biosynthesis of D-series Rv and PD. The potent actions of SPM in disease models in vivo are summarized in Table 18,9,20,21,40,42,47,49,51,52,54-69 and include results from our collaborators as well as many recent findings of other groups worldwide. Of interest, DPA (C22:5), an intermediate in humans for DHA, is a substrate for novel Rv-like LM. ${ }^{73}$

The first evidence was obtained for the conversion of DHA to unknown DHA-derived products in 1984 in retinal pigment cells using radiolabeled DHA and inhibitors. ${ }^{122}$ The structure of 10,17-docosatriene (neuroprotectin D1: NPD1), the founding member of the family of protectins, was first disclosed in a report on the isolation and elucidation of the bioactive resolvins. ${ }^{9}$ Because these DHAderived compounds were identified in resolving exudates, additional evidence was obtained for their biosynthesis from murine brain and vascular endothelial cells for the new bioactive products. ${ }^{9}$ These studies initially focused on aspirin and its impact in the biosynthesis of 17R-hydroxy-containing resolvins and related structures. Isolates of the novel DHA-derived products reduced cytokine IL-1 $\beta$ production by human glioma cells stimulated with TNF $\alpha$. Additionally, exudates obtained from mice given DHA, after extraction and transfer to other mice with peritonitis, reduced neutrophil infiltration in vivo, indicating the presence of potent bioactive products within the original inflammatory exudates. ${ }^{9,20}$

In parallel, experiments with isolated human cells were carried out to reconstruct potential biosynthetic routes. Human endothelial cells held in a hypoxic environment followed by inflammatory stimuli used DHA and EPA, converting each to intermediates taken up by human leukocytes and further transformed to bioactive products. ${ }^{8,9,54}$ Without aspirin treatment, 17S-HDHA and corresponding 17S-hydroxy-containing dihydroxy and tri-hydroxy products were identified in murine exudates and isolated human cells. ${ }^{9,20}$

DHA is well known for its essential role in neuronal development ${ }^{123}$ and, along with arachidonic acid, is a major PUFA found in the retina. ${ }^{122}$ As a family within the SPM genus, protectins are distinguished by the presence of a conjugated, triene-containing structure and enzymatic additions at carbon positions 10 and $17 .{ }^{115}$ The name "protectins" was coined from the observed antiinflammatory and organ-protective actions and systems. ${ }^{20,115}$ In studies in collaboration with Bazan et al, ${ }^{52}$ the prefix neuroprotectin, such as neuroprotectin D1 (NPD1), was used, giving the tissue location of their biosynthesis and local actions. ${ }^{115}$ The protectins stop PMN infiltration ${ }^{20,115}$ and are also biosynthesized by and act on glial cells to reduce cytokine expression ${ }^{20}$ (Figure 3; Table 1; 8,9,20,21,40,42,47,49,51,52,54-69). NPD1 reduces retinal and corneal injury ${ }^{52}$ and stroke damage from local tissue inflammation ${ }^{62}$ and improves corneal wound healing in mouse models. ${ }^{120}$

\section{Edema: A New Functional Role in Substrate Delivery for Resolution}

The mechanism of $\omega-3$ fatty acid mobilization in vivo during inflammation-resolution had not been addressed. Recently, we reported evidence for new mechanisms that indicate that unesterified or free $\omega-3$ fatty acids rapidly appear within exudates moving directly from the circulation to the site of inflammation. ${ }^{124}$ The movement of EPA and DHA parallels those of both plasma albumin proteins and trafficking leukocytes (Figure 4).

After ingestion, EPA and DHA are distributed throughout the human body. ${ }^{125} \mathrm{DHA}$ is predominantly distributed in retina, sperm, cerebral cortex, spleen, and red blood cells. EPA is present in muscle, liver, spleen, and red blood cells. ${ }^{126}$ Of note, DHA is esterified in phospholipids of microglial cells in culture and on activation of these cells, DHA is released from the phospholipids for enzymatic processing. ${ }^{20,62}$ The availability of unesterified EPA and DHA for processing during inflammation-resolution was of interest. The level of total fatty acids in human blood is approximately $343 \mathrm{mg} / 100 \mathrm{ml}$ plasma. ${ }^{127}$ Based on this and published values that range between 48 and $490 \mathrm{mg}$, free/unesterified EPA and DHA exist in human blood as basal levels (see references within 124).

Although native DHA and EPA themselves are thought to be anti-inflammatory, the specific mechanisms respon- 
sible are still evolving. The $\omega-3$ fatty acids are thought to replace the sn-2 position in phospholipid stores that are usually the positional sites of esterified $\omega-6$ fatty acids, such as arachidonic acid. ${ }^{125}$ The sn-2 position of phospholipids can become substituted with $\omega-3$ fatty acids (eg, DHA and EPA) and is currently thought to simply "compete" for these enzymatic reactions, thus blocking or preventing the utilization of arachidonate and production of specific eicosanoids that are proinflammatory and prothrombotic mediators. This view is consistent with results from both cultured and isolated cells in vitro when $\omega-3$ fatty acids are supplied. ${ }^{125}$

To address these points in a pathophysiological setting, ${ }^{124}$ we monitored both deuterium-labeled $d_{5}$-EPA and $d_{5}$-DHA levels from the circulation as well as increases in protein levels within exudates. Both $d_{5}$-EPA and $d_{5}$-DHA were identified in exudates within 1 hour of challenge, and levels were maintained up to 48 hours. At 48 hours, both $d_{5}$-EPA and $d_{5}$-DHA levels were significantly greater within the exudates than their levels at 24 hours. Thus, the initial or first peak of deuterium-labeled fatty acids was directly delivered from the circulation. The second peak at 48 hours likely reflects recirculation and expression of specific PLA $A_{2}$ during resolution.

Both cytosolic PLA ${ }_{2}$ and secretory PLA $A_{2}$ are highly expressed during the resolution phase. ${ }^{128}$ The second peak at 48 hours, well within the resolution phase, could be from esterified $d_{5}$-EPA and $d_{5}$-DHA and released by $\mathrm{PLA}_{2}$ mechanisms. The main protein component in exudates from zymosan-initiated peritonitis is serum albumin as demonstrated by 2D-gel electrophoresis and proteomics ${ }^{40}$; albumin is a well-known carrier of lipids, fatty acids, and particularly DHA. ${ }^{129}$ These results in mice suggest that EPA and DHA are directly mobilized for resolvin production from the circulation via albumin as the most abundant and likely main carrier into sites of inflammation. $M \Phi$ phagocytosis of apoptotic PMN releases RvE1, RvE2, PD1, and $\mathrm{LXA}_{4}{ }^{55}{ }^{5 X} \mathrm{~A}_{4}$ can then temporally limit edema through a feed-back mechanism (Figure 4), because it is a potent inhibitor of edema. ${ }^{130}$ This implies that, in humans, circulating levels of EPA and DHA do not require storage and subsequent release from complex lipid or membrane precursors to make important contributions to the control of inflammation and its resolution.

\section{Single-Cell Responses to DHA versus Resolvins}

Using a new microfluidic chamber approach to rapidly isolate human PMN within 5 minutes directly from circulating whole blood (only 5-10 $\mu$ l) via capture on P-selectin-coated surfaces, we assessed the direct actions of both precursor DHA versus one of its products, RvD1, on single neutrophil chemotaxis. Earlier procedures required the time-consuming isolation of PMN from whole blood before in vitro analyses. These methods involved several steps of centrifugation and red blood cell lysis that usually required several hours to perform and could lead to changes in the characteristics of the isolated cells. This short time interval is ideal for assessing the activation and/or inhibition status of PMN from peripheral blood of both healthy donors and patients. The combination of rapid separation as well as assessment of shape and migration responses within the same chamber is closely akin to in vivo scenarios on the endothelial surfaces via chemotaxis and migration into tissues (see ref. 1). Another key feature of the microfluidic chamber system is the ability to record real-time changes in morphology of PMN on exposure to chemokines, DHA, and lipid mediators, such as RvD1, as well as to track migration through switches. The fast gradient switches in the chamber allowed visual assessment and recording of the earliest events after exposure of cells to RvD1 or native DHA as well as precise measurement of these changes in migration direction and velocity. The direct assessment of DHA with PMN indicates that DHA itself is not a potent bioactive 'stop signal' for PMN but rather requires exudate conversion to RvD1 to evoke its signaling effects on these cells. Hence, following their actions, local tissues inactivate resolvins, permitting organs to return to homeostasis. ${ }^{48,131,132}$

\section{Inactivation of the Resolution Signals: Lessons from Injury Within}

Once formed, resolvins are active on target cells in their immediate milieu and are then locally inactivated by sitespecific metabolism. ${ }^{131,132}$ Ischemia-reperfusion is an event of significant clinical importance. Reperfusion-related tissue injury often occurs during surgical procedures, particularly those involving extremities, causing both local and remote organ injury as well as increasing costs associated with prolonged postoperative recovery. ${ }^{133}$ Given the clinical importance and pathophysiology of this type of organ injury, we investigated the direct actions of DHA, resolvins, and related stable analogs, that is, directly comparing the actions of RvD1, its 17-(R/ S)-methyl analog, RvE1, and its 19-p-fluorophenoxy analog, in ischemia-reperfusion second organ injury. Of interest, at equivalent doses, DHA was not protective, while RvD1 and its analog as well as the stable analog of RvE1 showed potent anti-leukocyte actions, each reducing infiltration into lung tissues. ${ }^{124}$

Native RvE1 itself was not able to protect the lung at these low doses, likely because of local inactivation. Both RvD1 and RvE1 undergo site-specific metabolic inactivation. ${ }^{131,132}$ Thus, the RvD1 and RvE1 analogs that display potent organ protective actions may provide new approaches to reduce organ damage characterized by excessive PMN infiltration.

\section{GPCR and Not Nuclear Receptors for SPM in Resolution}

At least two GPCRs are involved in transducing RvE1 signals, namely ChemR23 and BLT1. ${ }^{54,134}$ Because RvD1 biosynthesis and structure were established ${ }^{9}$ as well as its stereochemistry assigned ${ }^{48}$ (Figure 3 ) to identify sites of RvD1 action, we prepared synthetic $\left[{ }^{3} \mathrm{H}\right]-$ RvD1 and obtained evidence for specific RvD1 surface 
recognition on human leukocytes and identification of two GPCRs. The presence of RvD1-recognition sites on human phagocytes is of considerable interest in view of the potent actions of this autacoid. ${ }^{9,48,124}$ Two GPCRs denoted ALX, a lipoxin $\mathrm{A}_{4}$ receptor, and an orphan, GPR32, were identified as directly interacting with RvD1. In addition, RvD1 regulates phagocytosis by human $M \Phi$ in a receptor-dependent manner. ${ }^{135}$ Nanomolar concentrations of RvD1 blocked actin polymerization in PMN that were sensitive to inhibition by pertussis toxin, suggesting that the recognition sites belong to the family of GPCRs and most likely are coupled to G proteins of the Gi/o class. Screening systems used to assess PPAR activation indicated that neither RvD1 nor RvE1 directly activates PPAR signaling at concentrations that evoke antiinflammatory responses. ${ }^{135}$ Indeed, nuclear receptors belonging to the PPAR family have emerged as relevant in anti-inflammatory signaling mechanisms and may bind lipids. Oxidized fatty acids at concentrations in the micromolar range, for example, can activate PPAR $\gamma$, which possesses an unusually large ligand-binding cavity that can accommodate a wide range of molecules rather than a single ligand. ${ }^{136}$ Because RvD1 did not activate PPAR signaling within its bioactive concentration range, it was reasonable to determine whether the recognition sites were present on the surfaces of phagocytes belonging to the family of GPCRs.

We prepared $\left[{ }^{3} \mathrm{H}\right]-\mathrm{RvD} 1$ by total organic synthesis and used it to identify high-affinity, cell-surface recognition sites for RvD1 on human leukocytes, giving a $\mathrm{kDa}$ of approximately $0.2 \mathrm{nmol} / \mathrm{L}(\sim 75 \mathrm{pg} / \mathrm{ml})$, which is within the range of its levels measured in murine cells and tissues, that is, greater than $75-300 \mathrm{pg}^{34,61}$ and its bioactions. $\mathrm{LXA}_{4}$ partially displaced $\left[{ }^{3} \mathrm{H}\right]-\mathrm{RvD} 1$-specific binding to human PMN. A screening system for identifying receptor candidates, which tests the ability of receptor-ligand coupling to counteract TNF- $\alpha$-stimulated NF- $\kappa$ B activation, ${ }^{54}$ gave candidate GPCRs, namely ALX, a $L X A_{4}$ receptor, ${ }^{137}$ and an orphan, denoted GPR32. GPR32 consists of 356 deduced amino acids and shares sequence identity of 35-39\% homology with members of the chemoattractant receptor family. ${ }^{138}$

$\mathrm{LXA}_{4}$ and RVD1 share some anti-inflammatory and proresolving actions in human and murine systems, yet each is biosynthesized at different time intervals during resolution and via distinct biosynthetic routes. ${ }^{18}$ Proresolving lipid mediators exert their actions by interacting with GPCRs with high affinity and stereospecificity. For example, RvE1 binds both ChemR23 and BLT1 and LXA binds ALX-FPR2. ${ }^{54,134,139}$ Interestingly, these ligands bind to more than one receptor to mediate their actions, which in most cases are cell-type-specific. Recent results with ALX/FPR2-deficient mice confirm the interactions of $\mathrm{LXA}_{4}$ with this GPCR and its role in signaling anti-inflammatory responses. ${ }^{140}$ RvE1 stimulates proresolution pathways via ChemR23, which is abundantly expressed in $M \Phi$ and dendritic cells, ${ }^{54}$ whereas it binds to BLT1 for its anti-PMN actions. ${ }^{134}$ Along these lines, ChemR23-knockout mice are unable to resolve zymosaninduced peritonitis in the presence of $\mathrm{C}-15$, a peptide ligand for this receptor, indicating proresolving signaling by this receptor. ${ }^{118}$ The major postligand-binding signaling route for RvE1-ChemR23 interactions involves phosphorylation, leading to increased phagocytosis. ${ }^{141}$

\section{Proresolving Receptor Distribution}

Proresolving receptors identified thus far include human and mouse ALX/FPRL2, human and mouse ChemR23, and human GPR32. ${ }^{54,135,139}$ The distribution and function of human ALX/FPRL2 has been recently reviewed. ${ }^{137,142}$ Human ALX is present on PMN, monocytes, and T cells as well as resident cells, such as macrophages, synovial, fibroblasts, and intestinal epithelial cells. ${ }^{137}$ Its mRNA is also present in spleen, lung, placenta, and liver. ${ }^{107}$ In mouse tissues, ALX mRNA is also abundant in spleen and lung and, to a lesser extent, in heart and liver. ${ }^{107}$ Whether these mRNA levels change extensively during resolution is of interest. Human and mouse ChemR23, which interacts with RvE1, is abundant in monocytes with lower amounts in neutrophils and T lymphocytes. Several other human tissues express ChemR23, including cardiovascular system, brain, kidney, gastrointestinal, and myeloid. ${ }^{54}$ Human GPR32, an RvD1 receptor, and its expression were identified in peripheral blood leukocytes and arterial and venous tissue using cDNA array. This receptor appears on most human myeloid cells, PMN, monocytes, and macrophages as well as on the surfaces of human umbilical vein endothelial cells. The murine ortholog of GPR32 is currently unknown. Of interest during the course of resolution and disease is the expression and extent of these receptors, ${ }^{54}$ because earlier work indicated that overexpression of human ALX/FPR2 in murine leukocytes (a functional "knock-in") decreases the magnitude of the acute inflammatory response as well as shortens resolution time. ${ }^{143}$

\section{RvD2: Resolution and Sepsis}

Recently, we determined the stereochemistry of RvD2 ${ }^{42}$ with Dr. N. Petasis and colleagues and confirmed its originally identified and potent actions. ${ }^{9}$ As little as 0.01 to $0.1 \mathrm{ng}$ RvD2/mouse reduced PMN infiltration greater than $70 \%$ in peritonitis (Table 1,8,9,20,21,40,42,47,49,51,52,54-69). Several geometric isomers of RvD2 were prepared by total synthesis, ${ }^{42}$ and only the synthetic stereochemically defined compounds (confirmed by NMR of the synthetic materials, as in the case with $\mathrm{RvD}^{48}$ and $\mathrm{RvE} 1^{54}$ ) matched the properties and actions of RvD2 biosynthesized by human PMN (Figure 3). In mice with sepsis initiated by cecal ligation and puncture (CLP), RvD2 sharply reduced bacterial burden, leukocyte infiltration, and inflammatory cytokines, while the trans-RvD2 isomer was inactive. ${ }^{42}$ These multilevel proresolving actions of RvD2 gave increased survival and visible behavior improvements. These results with synthetic RvD2 confirm the original RvD2 structure and its potent actions ${ }^{9}$ as well as uncover the ability of this Rv to enhance both phagocytosis and intraphysosomal vacuole production of ROS for enhanced killing of bacteria by phagocytes. ${ }^{42}$ 


\section{Targeted Lipidomics in Late Phase, Self-Limited, Resolving Exudates Maresins}

In view of the actions of RvD1 and RvD2, ${ }^{9,20}$ we next monitored accumulation of 17S-HDHA as a pathway biomarker for activation of $\mathrm{Rv}$ and $\mathrm{PD}$ biosynthesis ${ }^{9}$ and endogenous conversion of DHA, as well as used targeted lipidomics to query whether other pathways were operative in resolution. In addition to 17S-HDHA, endogenous DHA was converted to 14S-hydroxydocosa$4 Z, 7 Z, 10 Z, 12 E, 16 Z, 19 Z$-hexaenoic acid (14S-HDHA). The appearance of $14 S-H D H A$ in resolving exudates accompanied 17-HDHA throughout the 72-hour time course, indicating that 14S-HDHA also accumulates in resolution and suggesting that it may be a marker of a new pathway. ${ }^{21} \mathrm{M} \Phi$ appear later in resolution to remodel and clear tissues. ${ }^{1,88}$ Indeed, human and mouse $\mathrm{M} \Phi$ converted 14S-HpDHA and DHA to new products identified via MS-based LM-lipidomics to novel bioactive 7,14-dihydroxy-containing products. ${ }^{21}$ Figure 2 illustrates the proposed hypothetical scheme for the maresin pathway and MaR1 biosynthesis. M $\Phi$ LOX converts DHA into 14S-HpDHA, followed by epoxidation to a 13(14)-epoxide intermediate that is enzymatically converted to the new bioactive mediator Maresin 1 or reduction of the peroxide intermediate to 14S-HDHA. Either 14S-HpDHA and/or 14S-HDHA is converted via LOX (double dioxygenation) to $7 S, 14 S-d i H D H A$ also identified in exudates. ${ }^{21}$ In addition to reducing PMN infiltration in vivo, the new $M \Phi$-derived compounds also enhanced phagocytosis. Given its potent actions and novel structure, the potent M $\Phi$ product was coined Maresin 1 (MaR1). MaR1 proved to be of comparable potency to synthetic RvE1 and PD1/NPD1.

\section{Too Much of a Good Thing? Bugs and SPM}

Certain pathogens have learned to use anti-inflammatory mediators such as LX to evade the host antimicrobial responses. ${ }^{144}$ During Toxoplasma gondii infections, local elevated LX levels block dendritic cell responses. ${ }^{145}$ The LX levels are superphysiologic, which enables the parasite to protect itself from phagocytes by stopping the recruitment. T. gondii carries its own 15-LO that we identified with proteomic analysis of tachyzoite-derived lysates, demonstrating peptides homologous to plant-derived type I LOX. ${ }^{146}$ These findings suggest that the enzyme can interact with substrates from the host to elevate LX. This was also independently observed in a genomic study of Pseudomonas aeruginosa, which carries the first-identified secretable form of 15-LO that can convert host arachidonic acid to its $L X$ precursor. ${ }^{147}$ When 15-LOX is injected into mice, it generates endogenous $L X$ that reduces inflammation and IL-12 production in vivo. ${ }^{146}$ Cystic fibrosis patients have frequent lung infections with $P$. aeruginosa, and they have a reduced capacity to biosynthesize LX. Uncontrolled accumulation of PMN in the lungs of these patients leads to organ failure. ${ }^{148}$ In these cases, treatment with $L X$ reduces airway inflammation and tissue damage with cystic fibro- sis, ${ }^{148}$ as also observed in asthma ${ }^{149}$ and respiratory inflammation. ${ }^{78}$

Candida albicans can produce RvE1 from host nutrients, which enhances phagocytosis, and ROS mediates killing of Candida while blocking the generation of IL-8 from epithelial cells and reducing the recruitment of PMN. ${ }^{91}$ Mycobacterium tuberculosis appears to evade the host's immune system by stimulating the biosynthesis of $\mathrm{LX}$ by the host, which assists the replication of $M$. tuberculosis in situ. ${ }^{150}$ Mycobacteria elimination versus necrotic cell death of the host $\mathrm{M} \Phi$ appears to be regulated by the local production of $L X A_{4}$ levels and their ratio to $P \mathrm{PE}_{2}$. ${ }^{151,152} \mathrm{LX}$ signaling for anti-inflammation, that is, down-regulated TNF $\alpha$, appears to be critical for mycobacteria infection in both humans and zebrafish. ${ }^{153}$ In addition, $\mathrm{LXA}_{4}$ given to fish infected with $M$. marinum increases replication of the microbe.

On the other hand, RvD2 reduces the bacterial burden following sepsis from CLP in mice when administered in very low doses. ${ }^{42}$ In these cases, the mechanisms of RvD2 action involves increases in bacterial phagocytosis and intracellular ROS-mediated killing of the bacteria. Thus, certain microbes have learned to commandeer chemical mediators, that is, specific SPM, and the resoIution mechanisms of the host to create a favorable local environment for their own survival, thus avoiding destruction.

\section{Resolution Indices and Toxicity}

To permit quantitative assessment of initiation and the most relevant parameters of resolution, quantifiable resolution indices were introduced. ${ }^{40,55}$ These indices track neutrophilic infiltration, their maxima, and the duration of their presence at inflammatory sites and within exudates. The use of these indices permitted the first evidence for demonstrating that resolvins and protectins reduce the amplitude of neutrophilic infiltration, but also shortened the resolution interval, which reflects the duration of the resolution phase. The use of these resolution intervals also permits assessments between species and organ systems for given agents. ${ }^{27}$ Additionally, because many current therapeutic agents are in use, such as nonsteroidals, anti-inflammatory drugs, etc, they were developed to reduce the initiation and amplitude of an inflammatory event, along with reducing the cardinal signs of inflammation, which can actually lead to an enhanced duration of the inflammatory response.

This is indeed the case with COX-2 inhibitors ${ }^{154}$ and aspirin, ${ }^{103}$ which block prostaglandin formation, which is relevant to resolution with several sites of action, as well as the traditional view of these substances in the initiation of inflammation. We introduced resolution indices to assess the impact of SPM and other agents on anti-inflammation and resolution. ${ }^{40}$ Most current anti-inflammatory drugs are inhibitors of pathways in inflammation; thus, they are not without unwanted side effects. ${ }^{97}$ These drugs affect resolution by blocking key resolution steps, prolonging inflammation, 89,154 which can be rescued by administering $\mathrm{LXA}_{4}, \mathrm{RvE} 1$, or PD1. ${ }^{55}$ Stable analogs of 
natural glucocorticoids do stimulate $M \Phi$ uptake of apoptotic $\mathrm{PMN}^{155}$ but are ultimately immunosuppressive. Thus, the use of resolution indices permits evaluation of endogenous mediators as in the case of SPM and their ability to shorten the resolution interval as well as screening of pharmacological agents for their impact in resolution, whether deleterious or beneficial. ${ }^{23,40}$ It appears that taking resolution into account in the development of new pharmacological agents will be valuable. The use of the resolution indices can also screen for agents that are toxic to resolution. ${ }^{55}$ Addition of a cyclooxygenase inhibitor, for example, can delay resolution by blocking the formation of resolvins and other proresolving mediators.

Recently, Navarro-Xavier surveyed a number of agents in zymosan-induced peritonitis and assessed resolution indices. They were also able to identify agents with proresolving properties. In addition to RvE1 and aspirintriggered 15-epi-lipoxin $\mathrm{A}_{4}$, a prostaglandin $\mathrm{D}_{2}$ receptor agonist appeared to possess proresolving actions in this proresolution, drug-screening strategy. ${ }^{23}$ The use of this type of system also permits discrimination between the actions of resolving macrophages and processes, such as efferocytosis. Thus, it is possible that many of the current therapeutics could be toxic to resolution. Interference within resolution mechanisms should be taken into account when considering new therapeutic approaches.

\section{Are All SPM the Same?}

By definition, SPM: i) are generated and/or accumulate within the resolution phase in vivo, ii) limit and reduce neutrophilic infiltration, iii) enhance phagocytic activity of macrophages toward apoptotic leukocytes, cellular debris, and microbes, and iv) stimulate the clearance of PMN from mucosal surfaces and their anti-microbial actions. If a mediator fulfills each of these and is produced in vivo, it then belongs to the genus of proresolving mediators. Each endogenous lipid mediator produced, such as lipoxins, resolvins, and protectins (as well as their aspirin-triggered forms), possesses additional compound-specific actions along with their general SPM properties uncovered both in vivo and in vitro that likely reflect target cell and tissue site biosynthesis and actions, as outlined in Figure 3.

Although some aspects of these responses appear redundant, the overall return from the battle of acute inflammation or catabasis is a critical event in homeostasis of an organ and organism. Therefore, it is not surprising if some of the biological responses and roles of SPM appear to overlap at this stage. Along these lines, the specific receptors identified that are expressed on target cell types may also answer the degree of selectivity and specificity of this proresolving system. In experimental inflammation and resolution model systems in vivo, it has been established that proresolving lipid mediators, such as RvE1 and NPD1, can shorten resolution time. ${ }^{23,55}$ These findings are encouraging, and results along these lines open the possibility for resolution-based pharmacology and new approaches to therapeutics.
Whether the encouraging results observed in animal disease models translate to human disease and their treatment remain to be determined. Along these lines, recent human trials in ocular iritis (dry eye) have yielded reduced signs and symptoms (http://eyedocnews.com/ 002059-resolvyx-announces-positive-data-from-trial-ofresolvin-rx-10045-for-dry-eye/, last accessed August 18, 2010). Hence, using endogenous proresolving mechanisms, and specifically SPM, as a means for resolutionbased therapeutics may have wide applications in treatment and prevention of human diseases.

The results reviewed herein also provide a potential mechanism of action for $\omega-3$ fatty acids in regulating the amplitude and duration of acute inflammatory responses via the formation of SPM (Table 1;,8,20,21,40,42,47,49,51,52,54-69). Whether a direct correlation exists in humans between dose or ingestion of $\omega-3$ fatty acids with local production of SPM at sites of inflammation remains of interest. In this context, the fat- 1 transgenic mouse, which endogenously produces and stores increased levels of $\omega-3$ EPA and DHA in tissues, on challenge, was found to biosynthesize increased levels of resolvins and protectins as well as 3-series prostaglandins from endogenous substrates. ${ }^{119}$ These results along with those of others $22,88,98$ emphasize the importance of endogenous resolution pathways as new approaches for treatments and clearly delineate the difference between molecules that can affect endogenous anti-inflammation versus those that evoke both anti-inflammatory and proresolving actions. Whether there are lipid mediators that stimulate only proresolving actions needs to be determined.

\section{Conclusion}

In summary, given the fundamental role of the acute inflammatory response and its natural resolution to homeostasis, it is not surprising that the SPM have proven to possess actions relevant to many disease models (Table $1 ;, 8,9,20,21,40,42,47,49,51,52,54-69)$. Because SPM limit neutrophilic infiltration as well as enhance macrophage resolution responses (Figures 3 and 4), the new pathways uncovered are likely to be relevant in maintaining tissue homeostasis as well as playing a role in diseases characterized by excessive uncontrolled inflammation. The link between $\omega$-3 fatty acids and their roles in resolution was unexpected and implies that the timing and duration of acute inflammation and its local resolution are linked to nutritional genomics and nutrition. Hence, it is intriguing that a process as fundamental as active resolution could be regulated by micronutrients and that edema plays a functional role in regulating the extent and duration of a resolving exudate. Because SPM are not immunosuppressive but rather enhance host defenses, stimulate resolution, and, hence, are proresolving, they may serve as agonists for new therapeutic approaches. In addition, it is clear from these early studies on SPM and endogenous termination programs that programmed resolution involves many mediators, pathways, and mechanisms yet to be uncovered and that anti-inflammation and its control are distinctly separate and not equivalent to the actions of local proresolving mediators that can also en- 
compass and regulate the magnitude of endogenous anti-inflammation. Thus, it is fortuitous that the SPM limit neutrophil entry and tissue damage as well as possess anti-inflammatory pharmacological actions in addition to stimulating proresolving pathways and enhancing host microbial defense mechanisms.

\section{Acknowledgments}

I thank Mary H. Small for expert assistance with manuscript preparation, the members of my laboratory and collaborators for their expertise and efforts in the reports referenced herein, and those not directly cited due to space limitations.

\section{References}

1. Cotran RS, Kumar V, Collins T: Robbins Pathologic Basis of Disease. Edited by Cotran RS, Kumar V, Collins T. Philadelphia, W.B. Saunders Co., 1999

2. Malech HL, Nauseef WM: Primary inherited defects in neutrophil function: etiology and treatment. Semin Hematol 1997, 34:279-290

3. Henson PM: Resolution of inflammation. Chest 1991, 99:2S-6S

4. Winyard PG, Willoughby DA: Inflammation Protocols. Edited by Winyard PG, Willoughby DA. Totowa NJ, Humana, 2003

5. Russell DG, Gordon S: Phagocyte-Pathogen Interactions: Macrophages and the Host Response to Infection. Edited by Russell DG, Gordon S. Washington, ASM Press, 2009

6. Ridker PM: Testing the inflammatory hypothesis of atherothrombosis: scientific rationale for the cardiovascular inflammation reduction trial (CIRT)0. J Thromb Haemost 2009, 7 (Suppl 1):332-339

7. Raison CL, Capuron L, Miller AH: Cytokines sing the blues: inflammation and the pathogenesis of depression. Trends Immunol 2006 27:24-31

8. Serhan CN, Clish CB, Brannon J, Colgan SP, Chiang N, Gronert K Novel functional sets of lipid-derived mediators with antiinflammatory actions generated from omega-3 fatty acids via cyclooxygenase 2-nonsteroidal antiinflammatory drugs and transcellular processing J Exp Med 2000, 192:1197-1204

9. Serhan CN, Hong S, Gronert K, Colgan SP, Devchand PR, Mirick G, Moussignac R-L: Resolvins: a family of bioactive products of omega-3 fatty acid transformation circuits initiated by aspirin treatment that counter pro-inflammation signals. J Exp Med 2002, 196:1025-1037

10. Serhan CN, Savill J: Resolution of inflammation: the beginning programs the end. Nat Immunol 2005, 6:1191-1197

11. Serhan CN, Brain SD, Buckley CD, Gilroy DW, Haslett C, O'Neill LAJ, Perretti M, Rossi AG, Wallace JL: Resolution of inflammation: state of the art, definitions and terms. FASEB J 2007, 21:325-332

12. Taggart CC, Greene CM, Carroll TP, O'Neill SJ, McElvaney NG Elastolytic proteases: inflammation resolution and dysregulation in chronic infective lung disease. Am J Respir Crit Care Med 2005, 171:1070-1076

13. Gough NR: Removing proinflammatory signals, Sci STKE 2006 , tw368

14. Michlewska S, Dransfield I, Megson IL, Rossi AG: Macrophage phagocytosis of apoptotic neutrophils is critically regulated by the opposing actions of pro-inflammatory and anti-inflammatory agents: key role for TNF-alpha. FASEB J 2009, 23:844-854

15. Haniffa MA, Collin MP, Buckley CD, Dazzi F: Mesenchymal stem cells: the fibroblasts' new clothes? Haematologica 2009, 94:258-263

16. Bystrom J, Evans I, Newson J, Stables M, Toor I, van Rooijen N, Crawford M, Colville-Nash P, Farrow S, Gilroy DW: Resolution-phase macrophages possess a unique inflammatory phenotype that is controlled by cAMP. Blood 2008, 112:4117-4127

17. Serhan CN, Chiang N: Endogenous pro-resolving and anti-inflammatory lipid mediators: a new pharmacologic genus. Br J Pharmacol 2008, 153 (Suppl. 1):S200-S215
18. Serhan CN: Resolution phases of inflammation: novel endogenous anti-inflammatory and pro-resolving lipid mediators and pathways. Annu Rev Immunol 2007, 25:101-137

19. Whelan J: Dietary stearidonic acid is a long chain (n-3) polyunsaturated fatty acid with potential health benefits. J Nutr 2009, 139:5-10

20. Hong S, Gronert K, Devchand P, Moussignac R-L, Serhan CN: Novel docosatrienes and 17S-resolvins generated from docosahexaenoic acid in murine brain, human blood and glial cells: autacoids in anti-inflammation. J Biol Chem 2003, 278:14677-14687

21. Serhan CN, Yang R, Martinod K, Kasuga K, Pillai PS, Porter TF, On SF, Spite M: Maresins: novel macrophage mediators with potent anti-inflammatory and pro-resolving actions. J Exp Med 2009, 206: 15-23

22. Rossi AG, Sawatzky DA: The Resolution of Inflammation. Edited by Rossi AG, Sawatzky DA. Basel, Birkhäuser Verlag AG, 2007

23. Navarro-Xavier RA, Newson J, Silveira VLF, Farrow SN, Gilroy DW, Bystrom J: A new strategy for the identification of novel molecules with targeted proresolution of inflammation properties. J Immunol 2010, 184:1516-1525

24. González-Périz A, Horrillo R, Ferré N, Gronert K, Dong B, MoránSalvador E, Titos E, Martínez-Clemente M, López-Parra M, Arroyo V, Clària J: Obesity-induced insulin resistance and hepatic steatosis are alleviated by omega-3 fatty acids: a role for resolvins and protectins. FASEB J 2009, 23:1946-1957

25. Morris T, Stables M, Hobbs A, de Souza P, Colville-Nash P, Warner T, Newson J, Bellingan G, Gilroy DW: Effects of low-dose aspirin on acute inflammatory responses in humans. J Immunol 2009, 183: 2089-2096

26. Bannenberg GL: Resolvins: current understanding and future potential in the control of inflammation. Curr Opin Drug Discov Deve 2009, 12:644-658

27. Seki $H$, Fukunaga $K$, Arita $M$, Arai $H$, Nakanishi $H$, Taguchi $R$, Miyasho T, Takamiya R, Asano K, Ishizaka A, Takeda J, Levy BD The anti-inflammatory and proresolving mediator resolvin E1 protects mice from bacterial pneumonia and acute lung injury. J Immunol 2010, 184:836-843

28. Tabas I: Macrophage death and defective inflammation resolution in atherosclerosis. Nat Rev Immunol 2010, 10:36-46

29. Kronke G, Katzenbeisser J, Uderhardt S, Zaiss MM, Scholtysek C, Schabbauer G, Zarbock A, Koenders MI, Axmann R, Zwerina J, Baenckler HW, van den Berg W, Voll RE, Kuhn H, Joosten LA, Schet G: 12/15-lipoxygenase counteracts inflammation and tissue damage in arthritis. J Immunol 2009, 183:3383-3389

30. Kataru RP, Jung K, Jang C, Yang H, Schwendener RA, Baik JE, Han $\mathrm{SH}$, Alitalo K, Koh GY: Critical role of CD11b + macrophages and VEGF in inflammatory lymphangiogenesis, antigen clearance, and inflammation resolution. Blood 2009, 113:5650-5659

31. Serhan CN, Chiang N, Van Dyke TE: Resolving inflammation: dual anti-inflammatory and pro-resolution lipid mediators. Nat Rev Immunol 2008, 8:249-261

32. Filep J: Lipid mediator interplay: resolvin D1 attenuates inflammation evoked by glutathione-conjugated lipid peroxidation products. $\mathrm{Br} \mathrm{J}$ Pharmacol 2009, 158:1059-1061

33. Li S, Sun Y, Liang C-P, Thorp EB, Han S, Jehle AW, Saraswathi V, Pridgen B, Kanter JE, Li R, Welch CL, Hasty AH, Bornfeldt KE, Breslow JL, Tabas I, Tall AR: Defective phagocytosis of apoptotic cells by macrophages in atherosclerotic lesions of ob/ob mice and reversal by a fish oil diet. Circ Res 2009, 105:1072-1082

34. Merched A, Ko K, Gotlinger KH, Serhan CN, Chan L: Atherosclerosis: evidence for impairment of resolution of vascular inflammation governed by specific lipid mediators. FASEB J 2008, 22:3595-3606

35. Serhan CN: guest ed.: Special Issue on Lipoxins and Aspirin-Triggered Lipoxins. Prostaglandins Leukot Essent Fatty Acids 2005 73(3-4):139-321

36. Rock KL, Kono H: The inflammatory response to cell death. Annu Rev Pathol Mech Dis 2008, 3:99-126

37. Cassatella MA: The Neutrophil. Edited by Cassatella MA. Basel, Karger 2003

38. Ganz T: Defensins: antimicrobial peptides of innate immunity. Nat Rev Immunol 2003, 3:710-720

39. Majno G: Inflammation and Infection: Historic Highlights. Edited by Majno G, Cotran RS, Kaufman N. Baltimore, Williams \& Wilkins, 1982, pp. 1-17

40. Bannenberg GL, Chiang N, Ariel A, Arita M, Tjonahen E, Gotlinger KH 
Hong S, Serhan CN: Molecular circuits of resolution: formation and actions of resolvins and protectins. J Immunol 2005, 174:4345-4355

41. Gao H, Neff $T$, Ward PA: Regulation of lung inflammation in the model of IgG immune-complex injury. Annu Rev Pathol Mech Dis 2006, 1:215-242

42. Spite M, Norling LV, Summers L, Yang R, Cooper D, Petasis NA, Flower RJ, Perretti M, Serhan CN: Resolvin D2 is a potent regulator of leukocytes and controls microbial sepsis. Nature 2009, 461:1287-1291

43. Campbell EL, Louis NA, Tomassetti SE, Canny GO, Arita M, Serhan CN, Colgan SP: Resolvin E1 promotes mucosal surface clearance of neutrophils: a new paradigm for inflammatory resolution. FASEB $J$ 2007, 21:3162-3170

44. McMahon B, Godson C: Lipoxins: endogenous regulators of inflammation. Am J Physiol Renal Physiol 2004, 286:F189-F201

45. Samuelsson B, Dahlen SE, Lindgren JA, Rouzer CA, Serhan CN Leukotrienes and lipoxins: structures, biosynthesis, and biological effects. Science 1987, 237:1171-1176

46. Funk CD: Prostaglandins and leukotrienes: advances in eicosanoid biology. Science 2001, 294:1871-1875

47. Arita M, Yoshida M, Hong S, Tjonahen E, Glickman JN, Petasis NA, Blumberg RS, Serhan CN: Resolvin E1, an endogenous lipid mediator derived from omega-3 eicosapentaenoic acid, protects against 2,4,6-trinitrobenzene sulfonic acid-induced colitis. Proc Natl Acad Sci USA 2005, 102:7671-7676

48. Sun Y-P, Oh SF, Uddin J, Yang R, Gotlinger K, Campbell E, Colgan SP, Petasis NA, Serhan CN: Resolvin D1 and its aspirin-triggered 17R epimer: stereochemical assignments, anti-inflammatory properties and enzymatic inactivation. J Biol Chem 2007, 282:9323-9334

49. Haworth O, Cernadas M, Yang R, Serhan CN, Levy BD: Resolvin E1 regulates interleukin-23, interferon-gamma and lipoxin $A_{4}$ to promote resolution of allergic airway inflammation. Nat Immunol 2008, 9:873-879

50. Aoki H, Hisada $T$, Ishizuka $T$, Utsugi M, Kawata $T$, Shimizu $Y$, Okajima F, Dobashi K, Mori M: Resolvin E1 dampens airway inflammation and hyperresponsiveness in a murine model of asthma. Biochem Biophys Res Commun 2008, 367:509-515

51. Connor KM, SanGiovanni JP, Lofqvist C, Aderman CM, Chen J, Higuchi A, Hong S, Pravda EA, Majchrzak S, Carper D, Hellstrom A, Kang JX, Chew EY, Salem NN Jr, Serhan CN, Smith LEH: Increased dietary intake of omega-3-polyunsaturated fatty acids reduces pathological retinal angiogenesis. Nat Med 2007, 13:868-873

52. Mukherjee PK, Marcheselli VL, Serhan CN, Bazan NG: Neuroprotectin D1: A docosahexaenoic acid-derived docosatriene protects human retinal pigment epithelial cells from oxidative stress. Proc Natl Acad Sci USA 2004, 101:8491-8496

53. Hasturk H, Kantarci A, Ohira T, Arita M, Ebrahimi N, Chiang N, Petasis NA, Levy BD, Serhan CN, Van Dyke TE: RvE1 protects from local inflammation and osteoclast mediated bone destruction in periodontitis. FASEB J 2006, 20:401-403

54. Arita M, Bianchini F, Aliberti J, Sher A, Chiang N, Hong S, Yang R, Petasis NA, Serhan CN: Stereochemical assignment, anti-inflammatory properties, and receptor for the omega-3 lipid mediator resolvin E1. J Exp Med 2005, 201:713-722

55. Schwab JM, Chiang N, Arita M, Serhan CN: Resolvin E1 and protectin D1 activate inflammation-resolution programmes. Nature 2007, 447:869-874

56. Jin Y, Arita M, Zhang Q, Saban DR, Chauhan SK, Chiang N, Serhan CN, Dana MR: Novel anti-inflammatory and pro-resolving lipid mediators block inflammatory angiogenesis. Invest Ophthalmol Vis Sci 2009, 50:4743-4752

57. Tian H, Lu Y, Sherwood AM, Hongqian D, Hong S: Resolvins E1 and D1 in choroid-retinal endothelial cells and leukocytes: biosynthesis and mechanisms of anti-inflammatory actions. Invest Ophthalmol Vis Sci 2009, 50:3613-3620

58. Ishida T, Yoshida M, Arita M, Nishitani Y, Nishiumi S, Masuda A, Mizuno S, Takagawa T, Morita Y, Kutsumi H, Inokuchi H, Serhan CN, Blumberg RS, Azuma T: Resolvin E1, an endogenous lipid derived from eicosapentaenoic acid, prevents dextran sulfate sodium-induced colitis. Inflamm Bowel Dis 2010, 16:87-95

59. Tjonahen E, Oh SF, Siegelman J, Elangovan S, Percarpio KB, Hong S, Arita M, Serhan CN: Resolvin E2: identification and anti-inflammatory actions: pivotal role of human 5-lipoxygenase in resolvin $\mathrm{E}$ series biosynthesis. Chem Biol 2006, 13:1193-1202
60. Ogawa S, Urabe D, Yokokura Y, Arai H, Arita M, Inoue M: Tota synthesis and bioactivity of resolvin E2. Org Lett 2009, 11:36023605

61. Duffield JS, Hong S, Vaidya V, Lu Y, Fredman G, Serhan CN, Bonventre JV: Resolvin D series and protectin D1 mitigate acute kidney injury. J Immunol 2006, 177:5902-5911

62. Marcheselli VL, Hong S, Lukiw WJ, Hua Tian X, Gronert K, Musto A Hardy M, Gimenez JM, Chiang N, Serhan CN, Bazan NG: Novel docosanoids inhibit brain ischemia-reperfusion-mediated leukocyte infiltration and pro-inflammatory gene expression. J Biol Chem 2003, 278:43807-43817

63. Marcheselli VL, Mukherjee PK, Arita M, Hong S, Antony R, Sheets K, Petasis N, Serhan CN, Bazan NG: Neuroprotectin D1/protectin D1 stereoselective and specific binding with human retinal pigment epithelial cells and neutrophils. Prostaglandins Leukot Essent Fatty Acids 2010, 82:27-34

64. Ariel A, Li P-L, Wang W, Tang W-X, Fredman G, Hong S, Gotlinger $\mathrm{KH}$, Serhan $\mathrm{CN}$ : The docosatriene protectin $\mathrm{D} 1$ is produced by $\mathrm{T}_{\mathrm{H}}{ }^{2}$ skewing and promotes human $T$ cell apoptosis via lipid raft clustering. J Biol Chem 2005, 280:43079-43086

65. Levy BD, Kohli P, Gotlinger K, Haworth O, Hong S, Kazani S, Israe E, Haley KJ, Serhan CN: Protectin D1 is generated in asthma and dampens airway inflammation and hyper-responsiveness. J Immunol 2007, 178:496-502

66. Hassan IR, Gronert K: Acute changes in dietary omega-3 and omega-6 polyunsaturated fatty acids have a pronounced impact on survival following ischemic renal injury and formation of renoprotective docosahexaenoic acid-derived protectin D1. J Immunol 2009, 182:3223-3232

67. Sheets KG, Zhou Y, Ertel MK, Knott EJ, Regan CE Jr, Elison JR, Gordon WC, Gjorstrup P, Bazan NG: Neuroprotectin D1 attenuates laser-induced choroidal neovascularization in mouse. Mol Vis 2010 16:320-329

68. He J, Bazan HE: Omega-3 fatty acids in dry eye and corneal nerve regeneration after refractive surgery. Prostaglandins Leukot Essent Fatty Acids 2010, 82:319-325

69. Lukiw WJ, Cui JG, Marcheselli VL, Bodker M, Botkjaer A, Gotlinger K, Serhan CN, Bazan NG: A role for docosahexaenoic acid-derived neuroprotectin D1 in neural cell survival and Alzheimer disease. J Clin Invest 2005, 115:2774-2783

70. Dona M, Fredman G, Schwab JM, Chiang N, Arita M, Goodarzi A, Cheng G, von Andrian UH, Serhan CN: Resolvin E1, an EPA-derived mediator in whole blood, selectively counterregulates leukocytes and platelets. Blood 2008, 112:848-855

71. Vassiliou EK, Kesler OM, Tadros JH, Ganea D: Bone marrow-derived dendritic cells generated in the presence of resolvin $\mathrm{E} 1$ induce apoptosis of activated CD4 ${ }^{+}$T cells. J Immunol 2008, 181:45344544

72. Levy BD, Clish CB, Schmidt B, Gronert K, Serhan CN: Lipid mediator class switching during acute inflammation: signals in resolution. Nat Immunol 2001, 2:612-619

73. Dangi B, Obeng M, Nauroth JM, Teymourlouei M, Needham M, Raman K, Arterburn LM: Biogenic synthesis, purification, and chemical characterization of anti-inflammatory resolvins derived from docosapentaenoic acid (DPAn-6). J Biol Chem 2009, 284:1474414759

74. Hao S, Baltimore D: The stability of mRNA influences the tempora order of the induction of genes encoding inflammatory molecules. Nat Immunol 2009, 10:281-288

75. Blaho VA, Buczynski MW, Brown CR, Dennis EA: Lipidomic analysis of dynamic eicosanoid responses during the induction and resolution of Lyme arthritis. J Biol Chem 2009, 284:21599-21612

76. Wu S-H, Liao P-Y, Yin P-L, Zhang Y-M, Dong L: Elevated expressions of 15-lipoxygenase and lipoxin $\mathrm{A}_{4}$ in children with acute poststreptococcal glomerulonephritis. Am J Pathol 2009, 174:115-122

77. Wu S-H, Liao P-Y, Yin P-L, Zhang Y-M, Dong L: Inverse tempora changes of lipoxin $\mathrm{A}_{4}$ and leukotrienes in children with HenochSchönlein purpura. Prostaglandins Leukot Essent Fatty Acids 2009 80:177-183

78. Kupczyk M, Antczak A, Kuprys-Lipinska I, Kuna P: Lipoxin $A_{4}$ generation is decreased in aspirin-sensitive patients in lysine-aspirin nasal challenge in vivo model. Allergy 2009, 64:1746-1752

79. Lawrence T, Gilroy DW: Chronic inflammation: a failure of resolution? Int J Exp Pathol 2006, 88:85-94 
80. Samuelsson B: Leukotrienes: mediators of immediate hypersensitivity reactions and inflammation. Science 1983, 220:568-575

81. Godson C, Mitchell S, Harvey K, Petasis NA, Hogg N, Brady HR: Cutting edge: lipoxins rapidly stimulate nonphlogistic phagocytosis of apoptotic neutrophils by monocyte-derived macrophages. J Immunol 2000, 164:1663-1667

82. Martins V, Valença SS, Farias-Filho FA, Molinaro R, Simões RS, Ferreira TPT, Silva PMR, Hogaboam CM, Kunkel SL, Fierro IM, Canetti C, Benjamim CF: ATLa, an aspirin-triggered lipoxin $A_{4}$ synthetic analog, prevents the inflammatory and fibrotic effects of bleomycin-induced pulmonary fibrosis. J Immunol 2009, 182:5374-5381

83. Ulrich CM, Bigler J, Potter JD: Non-steroidal anti-inflammatory drugs for cancer prevention: promise, perils and pharmacogenetics. Nat Rev Cancer 2007, 6:130-140

84. Maddox JF, Serhan $C N$ : Lipoxin $A_{4}$ and $B_{4}$ are potent stimuli for human monocyte migration and adhesion: selective inactivation by dehydrogenation and reduction. J Exp Med 1996, 183:137-146

85. Freire-de-Lima CG, Xiao YQ, Gardai SJ, Bratton DL, Schiemann WP, Henson PM: Apoptotic cells, through transforming growth factorbeta, coordinately induce anti-inflammatory and suppress pro-inflammatory eicosanoid and NO synthesis in murine macrophages. J Biol Chem 2006, 281:38376-38384

86. Serhan $\mathrm{CN}$ : Endogenous chemical mediators in anti-inflammation and pro-resolutionCurr Med Chem Anti Inflamm Anti Allergy Agents 2002, 1:177-192

87. Serhan CN: A search for endogenous mechanisms of anti-inflammation uncovers novel chemical mediators: missing links to resolution. Histochem Cell Biol 2004, 122:305-321

88. Gilroy DW, Lawrence T, Perretti M, Rossi AG: Inflammatory resolution: new opportunities for drug discovery. Nat Rev Drug Discov 2004, 3:401-416

89. Chiang N, Schwab JM, Fredman G, Kasuga K, Gelman S, Serhan $\mathrm{CN}$ : Anesthetics impact the resolution of inflammation. PLOS ONE 2008, 3:e1879

90. Tauber Al, Chernyak L: Metchnikoff and the Origins of Immunology: From Metaphor to Theory. New York, Oxford University Press, 1991

91. Haas-Stapleton EH, Lu Y, Hong S, Arita M, Favoreto S, Nigam S, Serhan CN, Agabian N: Candida albicans modulates host defense by biosynthesizing the pro-resolving mediator Resolvin E1. PLoS ONE 2007, 2:e1316

92. Canny G, Levy O, Furuta GT, Narravula-Alipati S, Sisson RB, Serhan CN, Colgan SP: Lipid mediator-induced expression of bactericidal/ permeability-increasing protein (BPI) in human mucosal epithelia. Proc Natl Acad Sci USA 2002, 99:3902-3907

93. Shimizu T: Lipid mediators in health and disease: enzymes and receptors as therapeutic targets for the regulation of immunity and inflammation. Annu Rev Pharmacol Toxicol 2009, 49:123-150

94. Andersson P, Serhan CN, Petasis NA, Palmblad J: Interactions between lipoxin $A 4$, the stable analogue 16-phenoxy-lipoxin A4 and leukotriene B4 in cytokine generation by human monocytes. Scand J Immunol 2004, 60:249-256

95. Ariel A, Fredman G, Sun Y-P, Kantarci A, Van Dyke TE, Luster AD, Serhan CN: Apoptotic neutrophils and T cells sequester chemokines during immune response resolution via modulation of CCR5 expression. Nat Immunol 2006, 7:1209-1216

96. Flower RJ: Prostaglandins, bioassay and inflammation. Br J Pharmacol 2006, 147:S182-S192

97. Vane JR, Botting RM: Therapeutic Roles of Selective COX-2 Inhibitors. Edited by Vane JR, Botting RM. London, William Harvey Press, 2001

98. Rossi AG, Sawatzky DA, Walker A, Ward C, Sheldrake TA, Riley NA, Caldicott A, Martinez-Losa M, Walker TR, Duffin R, Gray M, Crescenzi E, Martin MC, Brady HJ, Savill JS, Dransfield I, Haslett C: Cyclin-dependent kinase inhibitors enhance the resolution of inflammation by promoting inflammatory cell apoptosis. Nat Med 2006, 12:1056-1064

99. Wallace JL, Fiorucci S: A magic bullet for mucosal protection ... and aspirin is the trigger!. Trends Pharmacol Sci 2003, 24:323-326

100. Gilroy DW, Perretti M: Aspirin and steroids: new mechanistic findings and avenues for drug discovery. Curr Op Pharmacol 2005, 5:405-411

101. Birnbaum Y, Ye Y, Lin Y, Freeberg SY, Nishi SP, Martinez JD, Huang $\mathrm{M}-\mathrm{H}$, Uretsky BF, Perez-Polo JR: Augmentation of myocardial pro- duction of 15-epi-lipoxin-A4 by pioglitazone and atorvastatin in the rat. Circulation 2006, 114:929-935

102. Ye Y, Lin Y, Perez-Polo JR, Uretsky BF, Ye Z, Tieu BC, Birnbaum Y: Phosphorylation of 5 -lipoxygenase at ser523 by protein kinase $A$ determines whether pioglitazone and atorvastatin induce proinflammatory leukotriene B4 or anti-inflammatory 15-epi-lipoxin A4 production. J Immunol 2008, 181:3515-3523

103. Clària J, Serhan CN: Aspirin triggers previously undescribed bioactive eicosanoids by human endothelial cell-leukocyte interactions. Proc Natl Acad Sci USA 1995, 92:9475-9479

104. Chiang N, Bermudez EA, Ridker PM, Hurwitz S, Serhan CN: Aspirin triggers anti-inflammatory 15 -epi-lipoxin $\mathrm{A}_{4}$ and inhibits thromboxane in a randomized human trial. Proc Natl Acad Sci USA 2004 101:15178-15183

105. Chiang N, Hurwitz S, Ridker PM, Serhan CN: Aspirin has a genderdependent impact on anti-inflammatory 15 -epi-lipoxin $\mathrm{A}_{4}$ formation: a randomized human trial. Arterioscler Thromb Vasc Biol 2006, 26:14-17

106. Takano T, Clish CB, Gronert K, Petasis N, Serhan CN: Neutrophimediated changes in vascular permeability are inhibited by topical application of aspirin-triggered 15-epi-lipoxin $\mathrm{A}_{4}$ and novel lipoxin $B_{4}$ stable analogues. J Clin Invest 1998, 101:819-826

107. Takano T, Fiore S, Maddox JF, Brady HR, Petasis NA, Serhan CN Aspirin-triggered 15-epi-lipoxin $A_{4}$ and $L X A_{4}$ stable analogs are potent inhibitors of acute inflammation: evidence for anti-inflammatory receptors. J Exp Med 1997, 185:1693-1704

108. Svensson $\mathrm{Cl}$, Zattoni M, Serhan CN: Lipoxins and aspirin-triggered lipoxin stop inflammatory pain processing. J Exp Med 2007 204:245-252

109. Burr GO, Burr MM: A new deficiency disease produced by the rigid exclusion of fat from the diet. J Biol Chem 1929, 82:345-367

110. GISSI-Prevenzione Investigators: Dietary supplementation with n-3 polyunsaturated fatty acids and vitamin $E$ after myocardial infarction: results of the GISSI-Prevenzione trial. Gruppo Italiano per lo Studio della Sopravvivenza nell'Infarto miocardico. Lancet 1999 354:447-455

111. Simopoulos AP: Omega-3 fatty acids in inflammation and autoimmune diseases. J Am Coll Nutr 2002, 21:495-505

112. Calder PC: Polyunsaturated fatty acids and inflammatory processes: new twists in an old tale. Biochimie 2009, 91:791-795

113. León H, Shibata MC, Sivakumaran S, Dorgan M, Chatterley T, Tsuyuki RT: Effect of fish oil on arrhythmias and mortality: systematic review. BMJ 2008, 337:a2931

114. Serhan CN, Hong S, Lu Y: Lipid mediator informatics-lipidomics: novel pathways in mapping resolution. AAPS J 2006, 8:E284-E297

115. Serhan CN, Gotlinger K, Hong S, Lu Y, Siegelman J, Baer T, Yang R, Colgan SP, Petasis NA: Anti-inflammatory actions of neuroprotectin D1/protectin D1 and its natural stereoisomers: assignments of dihydroxy-containing docosatrienes. J Immunol 2006, 176:1848-1859

116. Arita M, Clish $C B$, Serhan $C N$ : The contributions of aspirin and microbial oxygenase in the biosynthesis of anti-inflammatory resolvins: novel oxygenase products from omega-3 polyunsaturated fatty acids. Biochem Biophy Res Commun 2005, 338:149-157

117. Todoric J, Löffler M, Huber J, Bilban M, Reimers M, Kadi A, Zeyda M, WaldhäusI W, Stulnig TM: Adipose tissue inflammation induced by high-fat diet in obese diabetic mice is prevented by n-3 polyunsaturated fatty acids. Diabetologia 2006, 49:2109-2119

118. Cash JL, Hart R, Russ A, Dixon JPC, Colledge WH, Doran J, Hendrick AG, Carlton MBL, Greaves DR: Synthetic chemerin-derived peptides suppress inflammation through ChemR23. J Exp Med 2008, 205:767-775

119. Hudert CA, Weylandt KH, Wang J, Lu Y, Hong S, Dignass A, Serhan $\mathrm{CN}$, Kang JX: Transgenic mice rich in endogenous n-3 fatty acids are protected from colitis. Proc Natl Acad Sci USA 2006, 103 $11276-11281$

120. Gronert K, Maheshwari N, Khan N, Hassan IR, Dunn M, Schwartzman ML: A role for the mouse 12/15-lipoxygenase pathway in promoting epithelial wound healing and host defense. J Biol Chem 2005 280:15267-15278

121. Serhan CN, Jain A, Marleau S, Clish C, Kantarci A, Behbehani B, Colgan SP, Stahl GL, Merched A, Petasis NA, Chan L, Van Dyke TE: Reduced inflammation and tissue damage in transgenic rabbits overexpressing 15-lipoxygenase and endogenous anti-inflammatory lipid mediators. J Immunol 2003, 171:6856-6865 
122. Bazan NG, Birkle DL, Reddy TS: Docosahexaenoic acid (22:6, n-3) is metabolized to lipoxygenase reaction products in the retina. Biochem Biophys Res Commun 1984, 125:741-747

123. Salem N Jr, Litman B, Kim H-Y, Gawrisch K: Mechanisms of action of docosahexaenoic acid in the nervous system. Lipids 2001, 36:945-959

124. Kasuga K, Yang R, Porter TF, Agrawal N, Petasis NA, Irimia D, Toner $M$, Serhan CN: Rapid appearance of resolvin precursors in inflammatory exudates: novel mechanisms in resolution. J Immunol 2008, 181:8677-8687

125. Lands B: A critique of paradoxes in current advice on dietary lipids. Prog Lipid Res 2008, 47:77-106

126. Arterburn LM, Hall EB, Oken H: Distribution, interconversion, and dose response of $\mathrm{n}-3$ fatty acids in humans. Am J Clin Nutr 2006, 83 (6 Suppl):1467S-1476S

127. Patil VS, Magar NG: Fatty acids of human blood. Biochem J 1960, 74:427-429

128. Gilroy DW, Newson J, Sawmynaden P, Willoughby DA, Croxtall JD: A novel role for phospholipase A2 isoforms in the checkpoint control of acute inflammation. FASEB J 2004, 18:489-498

129. Huang BX, Dass C, Kim HY: Probing conformational changes of human serum albumin due to unsaturated fatty acid binding by chemical cross-linking and mass spectrometry. Biochem J 2005, 387:695-702

130. Menezes-de-Lima O Jr, Kassuya CA, Nascimento AF, Henriques MG, Calixto JB: Lipoxin $\mathrm{A}_{4}$ inhibits edema in mice: implications for the anti-edematogenic mechanism induced by aspirin. Prostaglandins Oth Lipid Mediat 2006, 80:123-135

131. Arita M, Oh S, Chonan T, Hong S, Elangovan S, Sun Y-P, Uddin J, Petasis NA, Serhan CN: Metabolic inactivation of resolvin E1 and stabilization of its anti-inflammatory actions. J Biol Chem 2006, 281:22847-22854

132. Hong S, Porter TF, Lu Y, Oh SF, Pillai PS, Serhan CN: Resolvin E1 metabolome in local inactivation during inflammation-resolution. J Immunol 2008, 180:3512-3519

133. Gelman S: The pathophysiology of aortic cross-clamping and unclamping. Anesthesiology 1995, 82:1026-1060

134. Arita M, Ohira T, Sun YP, Elangovan S, Chiang N, Serhan CN Resolvin E1 selectively interacts with leukotriene $B_{4}$ receptor BLT1 and ChemR23 to regulate inflammation. J Immunol 2007, 178:3912-3917

135. Krishnamoorthy S, Recchiuti A, Chiang N, Yacoubian S, Lee C-H Yang R, Petasis NA, Serhan CN: Resolvin D1 binds human phagocytes with evidence for pro-resolving receptors. Proc Natl Acad Sci USA 2010, 107:1660-1665

136. Itoh T, Fairall L, Amin K, Inaba Y, Szanto A, Balint BL, Nagy L, Yamamoto K, Schwabe JWR: Structural basis for the activation of PPARgamma by oxidized fatty acids. Nat Struct Mol Biol 2008, 15:924-931

137. Chiang N, Serhan CN, Dahlén S-E, Drazen JM, Hay DWP, Rovati GE, Shimizu T, Yokomizo T, Brink C: The lipoxin receptor ALX: potent ligand-specific and stereoselective actions in vivo. Pharmacol Rev 2006, 58:463-487

138. Marchese A, Nguyen T, Malik P, Xu S, Cheng R, Xie Z, Heng HH, George SR, Kolakowski LF Jr, O'Dowd BF: Cloning genes encoding receptors related to chemoattractant receptors. Genomics 1998, $50: 281-286$

139. Fiore S, Maddox JF, Perez HD, Serhan CN: Identification of a human cDNA encoding a functional high affinity lipoxin $\mathrm{A}_{4}$ receptor. J Exp Med 1994, 180:253-260
140. Dufton NP, Hannon R, Brancaleone V, Dalli J, Patel HB, Gray M, D'Acquisto F, Buckingham JC, Perretti M, Flower RJ: Anti-inflammatory role of the murine formyl-peptide receptor 2: ligand-specific effects on leukocyte responses and experimental inflammation. J Immunol 2010, 184:2611-2619

141. Ohira T, Arita M, Omori K, Recchiuti A, Van Dyke TE, Serhan CN: Resolvin $\mathrm{E} 1$ receptor activation signals phosphorylation and phagocytosis. J Biol Chem 2009, 285:3451-3461

142. Ye RD, Boulay F, Wang JM, Dahlgren C, Gerard C, Parmentier M, Serhan CN, Murphy PM: International Union of Basic and Clinical Pharmacology LXXIII: Nomenclature for the formyl peptide receptor (FPR) family. Pharmacol Rev 2009, 61:119-161

143. Devchand PR, Arita M, Hong S, Bannenberg G, Moussignac R-L, Gronert K, Serhan CN: Human ALX receptor regulates neutrophil recruitment in transgenic mice: roles in inflammation and host-defense. FASEB J 2003, 17:652-659

144. Sacks D, Sher A: Evasion of innate immunity by parasitic protozoa. Nat Immunol 2002, 3:1041-1047

145. Aliberti J, Reis e Sousa C, Schito M, Hieny S, Wells T, Huffnagle GB, Sher A: CCR5 provides a signal for microbial induced production of IL-12 by CD8 alpha + dendritic cells. Nat Immunol 2000, 1:83-87

146. Bannenberg GL, Aliberti J, Hong S, Sher A, Serhan CN: Exogenous pathogen and plant 15-lipoxygenase initiate endogenous lipoxin $A_{4}$ biosynthesis. J Exp Med 2004, 199:515-523

147. Vance RE, Hong S, Gronert K, Serhan CN, Mekalanos JJ: The opportunistic pathogen Pseudomonas aeruginosa carries a nove secretable arachidonate 15-lipoxygenase. Proc Natl Acad Sci USA 2004, 101:2135-2139

148. Karp CL, Flick LM, Park KW, Softic S, Greer TM, Keledjian R, Yang R, Uddin J, Guggino WB, Atabani SF, Belkaid Y, Xu Y, Whitsett JA, Accurso FJ, Wills-Karp M, Petasis NA: Defective lipoxin-mediated anti-inflammatory activity in the cystic fibrosis airway. Nat Immunol 2004, 5:388-392

149. Levy BD, De Sanctis GT, Devchand PR, Kim E, Ackerman K, Schmidt BA, Szczeklik W, Drazen JM, Serhan CN: Multi-pronged inhibition of airway hyper-responsiveness and inflammation by lipoxin $\mathrm{A}_{4}$. Nat Med 2002, 8:1018-1023

150. Bafica A, Scanga CA, Serhan C, Machado F, White S, Sher A, Aliberti $\mathrm{J}$ : Host control of Mycobacterium tuberculosis is regulated by 5-lipoxygenase-dependent lipoxin production. J Clin Invest 2005 115:1601-1606

151. Behr M, Schurr E, Gros P: TB: screening for responses to a vile visitor. Cell 2010, 140:615-618

152. Chen M, Divangahi M, Gan H, Shin DS, Hong S, Lee DM, Serhan CN, Behar SM, Remold HG: Lipid mediators in innate immunity against tuberculosis: opposing role of $P G E_{2}$ and $L X A_{4}$ in the induction of macrophage death. J Exp Med 2008, 205:2791-2801

153. Tobin DM, Vary JC Jr, Ray JP, Walsh GS, Dunstan SJ, Bang ND, Hagge DA, Khadge S, King M-C, Hawn TR, Moens CB, Ramakrishnan L: The Ita4h locus modulates susceptibility to mycobacterial infection in zebrafish and humans. Cell 2010, 140:717-730

154. Gilroy DW, Colville-Nash PR, Willis D, Chivers J, Paul-Clark MJ, Willoughby DA: Inducible cycloxygenase may have anti-inflammatory properties. Nat Med 1999, 5:698-701

155. Heasman SJ, Giles KM, Ward C, Rossi AG, Haslett C, Dransfield I: Glucocorticoid-mediated regulation of granulocyte apoptosis and macrophage phagocytosis of apoptotic cells: implications for the resolution of inflammation. J Endocrinol 2003, 178:29-36 